\title{
Olive (Olea europaea) Leaf Extract Induces Apoptosis and Monocyte/Macrophage Differentiation in Human Chronic Myelogenous Leukemia K562 Cells: Insight into the Underlying Mechanism
}

\author{
Imen Samet, ${ }^{1}$ Junkyu Han, ${ }^{2,3}$ Lobna Jlaiel, ${ }^{4}$ Sami Sayadi, ${ }^{4}$ and Hiroko Isoda ${ }^{2,3}$ \\ ${ }^{1}$ Graduate School of Life and Environmental Sciences, University of Tsukuba, Tennodai 1-1-1, Tsukuba, Ibaraki 305-8572, Japan \\ ${ }^{2}$ Faculty of Life and Environmental Sciences, University of Tsukuba, Tennodai 1-1-1, Tsukuba, Ibaraki 305-8572, Japan \\ ${ }^{3}$ Alliance of Research on North Africa, University of Tsukuba, Tennodai 1-1-1, Tsukuba, Ibaraki 305-8572, Japan \\ ${ }^{4}$ Laboratory of Environmental Bioprocesses, Biotechnology Center of Sfax, Sfax 3018, Tunisia
}

Correspondence should be addressed to Hiroko Isoda; isoda.hiroko.ga@u.tsukuba.ac.jp

Received 6 December 2013; Accepted 16 February 2014; Published 6 April 2014

Academic Editor: Elisa Cabiscol

Copyright (C) 2014 Imen Samet et al. This is an open access article distributed under the Creative Commons Attribution License, which permits unrestricted use, distribution, and reproduction in any medium, provided the original work is properly cited.

Differentiation therapy is an attractive approach aiming at reversing malignancy and reactivating endogenous differentiation programs in cancer cells. Olive leaf extract, known for its antioxidant activity, has been demonstrated to induce apoptosis in several cancer cells. However, its differentiation inducing properties and the mechanisms involved are still poorly understood. In this study, we investigated the effect of Chemlali Olive Leaf Extract (COLE) for its potential differentiation inducing effect on multipotent leukemia K562 cells. Results showed that COLE inhibits K562 cells proliferation and arrests the cell cycle at G0/G1, and then at G2/M phase over treatment time. Further analysis revealed that COLE induces apoptosis and differentiation of K562 cells toward the monocyte lineage. Microarray analysis was conducted to investigate the underlying mechanism of COLE differentiation inducing effect. The differentially expressed genes such as IFI16, EGR1, NFYA, FOXP1, CXCL2, CXCL3, and CXCL8 confirmed the commitment of K562 cells to the monocyte/macrophage lineage. Thus our results provide evidence that, in addition to apoptosis, induction of differentiation is one of the possible therapeutic effects of olive leaf in cancer cells.

\section{Introduction}

Several advances against cancer have been recently achieved thanks to different therapeutic modalities, with radiation and chemotherapy being the most used so far. Although these therapies have been proven successful against some tumors, they are still highly toxic and nonspecific, since their primary mode of action is DNA damage, which results in severe adverse effects for normal cells [1]. Differentiation inducing therapy is therefore anticipated as a novel medical treatment that could reduce such adverse effects. This new concept which consists in forcing malignant cells to undergo terminal differentiation instead of killing them through cytotoxicity has so far gained a great interest especially for treating leukemia. Many compounds have been reported to induce differentiation of leukemia cells and some of them are already approved for clinical use [2]. Natural products have greatly contributed to cancer therapy and a rising interest is being attributed to the identification of new compounds from the plant resources with relevant effects against cancer development $[3,4]$. Some of these compounds are now being used in clinical practice such as All-Trans Retinoic Acid. Recent basic research studies and observational epidemiologic studies strongly support that the disease-preventing effects of natural products are in part attributed to antioxidants, even though their efficiency in vivo needs more investigations [5].

Olive leaves contain many potentially bioactive compounds that may have antioxidant, antimicrobial, antihypertensive, antiviral, anti-inflammatory, hypoglycemic, neuroprotective, and anticancer properties [6-14]. Olive leaf has 
gained the rising interest of the scientific and industrial community due to its proved beneficial health properties and thus has emerged as commercially valuable nutraceuticals [15]. The primary constituents which are believed to contribute to the health benefits of olive leaves are Oleuropein, Hydroxytyrosol, as well as several other flavonoids, such as Verbascoside, Apigenin-7-glucoside, and Luteolin7 -glucoside $[14,16]$. Oleuropein, the major constituent of olive leaves, has been shown to be a potent antioxidant. Its radical scavenging activity has been well documented $[6,17]$. Oleuropein has been shown to inhibit the oxidation of low density lipoproteins in vitro and in vivo [18]. Jemai et al. have demonstrated that polyphenols recovered from olive leaf extracts, Oleuropein, Hydroxytyrosol, and Oleuropein aglycone, exhibited a pronounced hypolipidemic effect, reduced the lipid peroxidation process, and enhanced the antioxidant defense system in experimental atherogenic model [19]. Benavente-García et al., [17], studied the antioxidant activity of phenolic compounds from olive leaves and concluded that olive phenols may exhibit synergistic behavior in their radical scavenging capacity when mixed in the same proportions as occur in the olive leaf extract. Two recent studies have focused on the bioavailability of olive leaf phenolic compounds in human subjects and have come to the conclusion that Oleuropein is rapidly absorbed and metabolized to be mainly excreted as glucuronidated and sulfated Hydroxytyrosol, suggesting that olive leaf extract could exert benefits against oxidative stress-related processes in vivo $[15,20]$.

In the prior studies, olive leaf extract has been shown to exhibit an antitumor activity and to induce apoptosis pathways in cancer cells; little attention has been paid to its effect on the process of cancer cell differentiation. Particularly, olive leaf has been reported to exhibit an antileukemia effect by inducing apoptosis in the acute myeloid leukemia HL-60 cells $[13,21]$.

In this study, we investigate the effect of olive leaf of the most abundant Tunisian variety, Chemlali, on the human chronic myeloid leukemia K562 cells. Compared to the leukemia cell lines used in previous studies [13, 21], K562 cells can be regarded as stem-like cells thanks to their pluripotency [22] and are known for their strong resistance to chemical inducers [23].

We speculate that olive leaf extract may have anticarcinogenic property in K562 cells not only by inducing apoptosis but also by inducing the commitment of leukemia cells to the maturation process in order to progressively give an apparent normal cell life.

\section{Materials and Methods}

2.1. Preparation of Olive Leaf Extract. Collected olive leaves of Chemlali variety from the region of Sfax, Tunisia, were air-dried and ground with a mixer. Extraction was carried by ethanol $70 \%(1 / 10, \mathrm{w} / \mathrm{v})$ in darkness for 2 weeks at room temperature. The mixture was then centrifuged and filtered using $0,45 \mu \mathrm{m}$ filter (Millipore, Japan) and stored at $-80^{\circ} \mathrm{C}$ until it was used.
2.2. HPLC Analysis. Chromatographic analyses were achieved on an Agilent series 1260 HPLC-DAD instrument (Agilent, Waldbronn, Germany). The instrument includes a quaternary pump, an online degasser, an autosampler, and a thermostatically controlled column compartment. Chromatographic separation was carried out on a ZORBAX Eclipse XDB-C18 column serial number USNH027266 (4.6 mm I.D. $\times 250 \mathrm{~mm} \times 3.5 \mu \mathrm{m}$ particle size). The elution conditions were as follows: mobile phase A $(0.1 \%$ acetic acid in water) and mobile phase $\mathrm{B}$ (100\% acetonitrile), flow rate of $0.5 \mathrm{~mL} / \mathrm{min}$, sample injection volume of $10 \mu \mathrm{L}$, and operating temperature $40^{\circ} \mathrm{C}$. The running gradient was as follows: 0$22 \mathrm{~min}, 10 \%-50 \% \mathrm{~B} ; 22-32 \mathrm{~min}, 50 \%-100 \% \mathrm{~B} ; 32-40 \mathrm{~min}$, $100 \% \mathrm{~B} ; 40-44 \mathrm{~min}, 100-10 \%$ B. Reequilibration duration lasted $6 \mathrm{~min}$. The DAD detector scanned from 190 to $400 \mathrm{~nm}$ and the samples were detected at 254,280, and $330 \mathrm{~nm}$.

2.3. Cell Line and Culture Conditions. Human chronic leukemia cell line K562 was obtained from the Riken Cell Bank (Tsukuba, Ibaraki, Japan). Cells were cultured in RPMI 1640 medium (Gibco), supplemented with $10 \%$ heat-inactivated fetal bovine serum, and maintained at $37^{\circ} \mathrm{C}$ in a humidified incubator with $5 \% \mathrm{CO}_{2}$. The cells were pass-cultured every 3 days and used for experiments after reaching the exponential growth phase.

2.4. Cell Proliferation Assay. Cell proliferation was investigated by MTT (3-(4,5-dimethylthiazol-2-yl)-2,5diphenyltetrazolium bromide) assay. K562 cells were seeded in 96-well plates at $2.0 \times 10^{4}$ cells $/ \mathrm{mL}$. After incubation for $24 \mathrm{~h}$, olive leave extract diluted in medium was added at final concentrations of $50,75,100,125$, and $150 \mu \mathrm{g} / \mathrm{mL}$. Control cells were treated by ethanol at a final concentration of $0.3 \%$. MTT was added after treatment for 24,48 , and $72 \mathrm{~h}$ and the resulting formazan was completely dissolved by $100 \mu \mathrm{L}$ of $10 \%$ sodium dodecyl sulfate (SDS) for $24 \mathrm{~h}$. The absorbance was determined at $570 \mathrm{~nm}$ in a multidetection microplate reader (Powerscan HT, Dainippon Pharmaceutical, NJ, USA). Absorbance caused by the ability of the sample to reduce MTT or by its color was corrected using plates prepared in the same conditions in the absence of cells.

2.5. Cell Viability Assay and Cell Morphological Changes. The viability of COLE treated cells was measured using flow cytometry according to the manufacturer instructions. K562 cells were seeded in 6 -well plates at $2.0 \times 10^{4}$ cells $/ \mathrm{mL}$ and treated the following day by 50,100 , and $150 \mu \mathrm{g} / \mathrm{mL}$ of COLE diluted in medium and $0.3 \%$ ethanol in the case of the control. After incubation for the indicated time, treated cells were harvested, suspended in Guava ViaCount reagent, and allowed to be stained for at least $5 \mathrm{~min}$ in darkness. The cell number and viability were measured by Guava PCA flow cytometry (Guava Technologies, CA, USA). Morphological changes were detected by observation under a phase contrast microscope (Leica Microsystem).

2.6. Cell Cycle Analysis. The distribution of the cell cycle phases of treated and control cells was analysed by flow 
cytometry. Briefly, $2.0 \times 10^{4}$ cells $/ \mathrm{mL}$ of $\mathrm{K} 562$ cells were seeded in 6 -well plates and treated by 100 and $150 \mu \mathrm{g} / \mathrm{mL}$ of COLE diluted in medium. Control cells were treated with ethanol $0.3 \%$. After the desired time of incubation, cells were harvested, washed twice with PBS, and fixed with $70 \%$ ethanol at $4^{\circ} \mathrm{C}$ for more than $12 \mathrm{~h}$. The fixed cells were then centrifuged at $500 \times \mathrm{g}$ for $5 \mathrm{~min}$ and washed with PBS twice. Cell cycle reagent (Guava Technologies) was added, and the cells were kept in darkness for $30 \mathrm{~min}$ at room temperature. The population of cells in each cell cycle phase was determined by a Guava PCA flow cytometry according to their DNA content.

2.7. Annexin $V$ Assay. The induction of apoptosis in treated cells was determined by measuring the externalization of phosphatidylserine (PS) to the cell surface by flow cytometry. K562 cells were seeded in 6 well plates and treated with 50, 100 and $150 \mathrm{ug} / \mathrm{mL}$ of COLE diluted in medium. Control cells were treated with ethanol $0.3 \%$. When reaching the desired treatment time, cells were harvested and stained with Guava Nexin Reagent. Then, cells were incubated for $20 \mathrm{~min}$ at room temperature in the dark and then acquired on the Guava PCA system.

2.8. Cell Differentiation Assay. Cell differentiation was assessed by flow cytometry by measuring the expression of CD11b and CD14 on the surface of K562 cells. Cells were seeded at $2.0 \times 10^{4}$ cells $/ \mathrm{mL}$ in 6 -well plates and incubated for $24 \mathrm{~h}$. The COLE diluted in medium was added at final concentrations of 50,100 , and $150 \mu \mathrm{g} / \mathrm{mL}$ and ethanol at $0.3 \%$ in the case of control cells. After incubation, cells were harvested, washed twice with cold PBS, and adjusted to the same number $1.0 \times 10^{5}$. The cells were then labeled with phycoerythrin conjugated anti-CD14, anti-CD11b, anti-CD41, and anti-glycophorin $\mathrm{A}$ for $30 \mathrm{~min}$ according to manufacturer's instructions. The stained cells were washed twice with cold PBS and resuspended in $500 \mu \mathrm{L}$ PBS for measurement.

2.9. Total RNA Isolation. K562 cells at a concentration of $2.0 \times 10^{4}$ cells $/ \mathrm{mL}$ were incubated for $24 \mathrm{~h}$ and then treated with 100 and $150 \mu \mathrm{g} / \mathrm{mL}$ of COLE for $72 \mathrm{~h}$. The control cells were treated with ethanol at final concentration of $0.3 \%$. The cells were then collected and washed with PBS. DNAfree total RNA was isolated from the cells using Isogen reagent (Nippon Gene Co., Tokyo, Japan) following the manufacturer's instructions.

2.10. DNA Microarray Analysis. Microarray hybridization probes were generated from isolated RNA samples. Doublestranded cDNA was synthesized from 100 ng of total RNA using the GeneAtlas $3^{\prime}$ IVT Express Kit (Affymetrix, Inc.). Biotin-labeled aRNA was synthesized by in vitro transcription and purified. $10 \mu \mathrm{g}$ of purified aRNA was then fragmented using the GeneAtlas $3^{\prime}$ IVT Express Kit and was hybridized to the Affymetrix HG-U219 (Affymetrix) for $16 \mathrm{~h}$ at $45^{\circ} \mathrm{C}$. The chips were washed and stained in the GeneAtlas Fluidics Station 400 (Affymetrix) and then imaged in the
TABLE 1: Retention time and concentration of the main phenolic compounds present in Chemlali Olive Leaf Extract (COLE).

\begin{tabular}{lccc}
\hline $\begin{array}{l}\text { Peak } \\
\text { number }\end{array}$ & $\begin{array}{c}\text { Retention time } \\
(\mathrm{min})\end{array}$ & $\begin{array}{c}\text { Amount } \\
(\mathrm{mg} / \mathrm{mL})\end{array}$ & Compound \\
\hline 1 & 9.91 & 0.108 & Hydroxytyrosol \\
2 & 15.225 & 0.047 & Verbascoside \\
3 & 15.634 & 0.536 & Luteolin-7-glucoside \\
4 & 17.344 & 0.529 & Apigenin-7-glucoside \\
5 & 18.737 & 7.453 & Oleuropein \\
6 & 22.127 & 0.089 & Luteolin \\
7 & 25.056 & 0.012 & Apigenin \\
\hline
\end{tabular}

GeneAtlas Imaging Station (Affymetrix). The Partek Express software (Affymetrix) served for the data analysis by running comparisons of gene expression in treated and control cells based on mathematical algorithms. The generated data (significant fold change in gene expression) was then analyzed using the Pathway Studio Explore 1.1 software (Affymetrix).

2.11. Statistical Analysis. Data are presented as the mean \pm SD of three independent experiments. Statistical analyses of changes, for each time and concentration point compared to the control, were performed using a paired two-tailed Student's $t$-test. A $P$ value $<0.05$ was considered statistically significant.

\section{Results}

3.1. Composition of COLE. In order to identify and quantify the main compounds present in COLE, HPLC analysis was performed. Compounds were identified by comparing each peak's retention time with that of injected reference standards in the same chromatographic conditions. Only Oleuropein was detected at $254 \mathrm{~nm}$ while the two other phenylethanoids, Hydroxytyrosol and Verbascoside, as well as the flavonoids Apigenin and Luteolin and their glucoside forms were detected at $330 \mathrm{~nm}$ (Figure 1). The retention time (min) and the amount $(\mathrm{mg} / \mathrm{mL})$ of each detected compound are listed in Table 1. Oleuropein was the major compound in the extract, present at a concentration of $7.453 \mathrm{mg} / \mathrm{mL}$. Luteolin-7-glucoside and Apigenin-7-glucoside were present at 0.536 and $0.529 \mathrm{mg} / \mathrm{mL}$, respectively. The other detected compounds, Hydroxytyrosol, Verbascoside, Apigenin, and Luteolin, were present as traces.

The antioxidant activity of Chemlali Olive Leaf Extract was confirmed by the DPPH radical scavenging assay according to Enujiugha et al. [24]. Data showed that the radical scavenging activity of COLE increased in a dose dependent manner and that the extract concentration providing 50\% inhibition of free radicals (IC50) was $0.6 \mathrm{mg} / \mathrm{mL}$ (data not shown).

3.2. COLE Inhibits the Proliferation of K562 Cells. To evaluate the antileukemia effect of COLE on K562 cells, different concentrations from 50 to $150 \mu \mathrm{g} / \mathrm{mL}$ were applied on $\mathrm{K} 562$ cells for the MTT assay. Treatment for 24,48 , and $72 \mathrm{~h}$ 


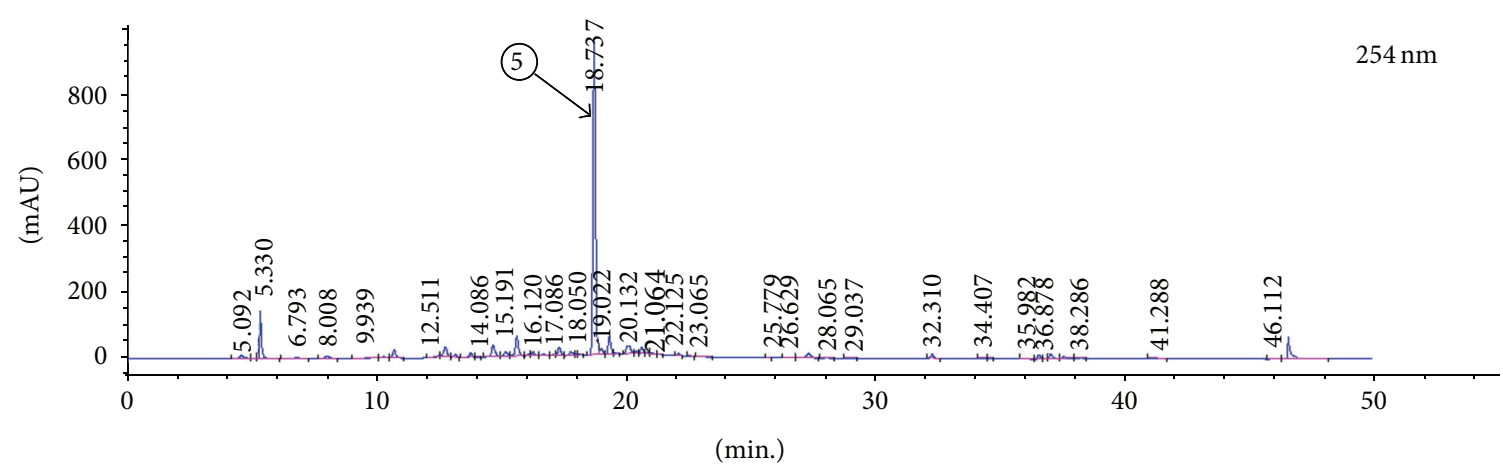

(a)

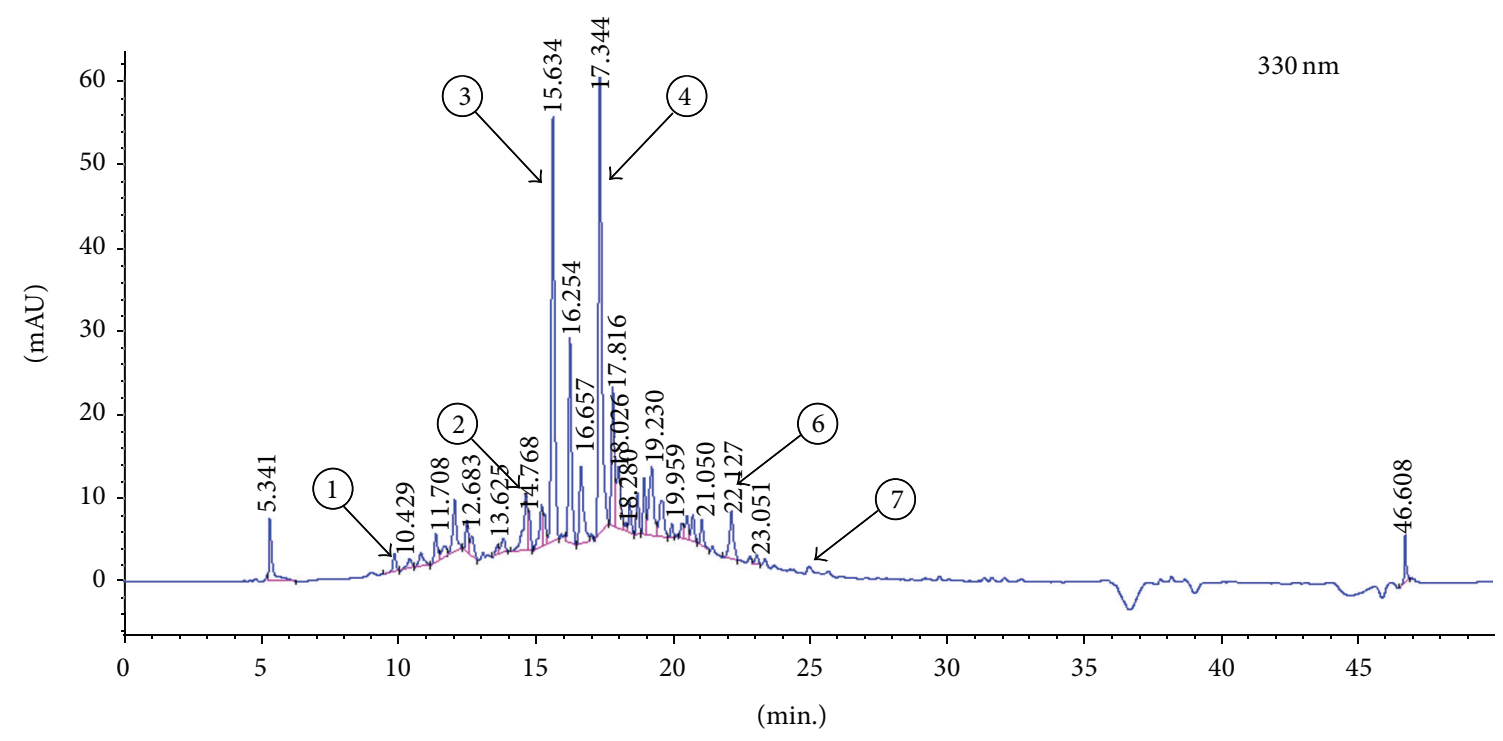

(b)

FIGURE 1: HPLC chromatogram of Chemlali Olive Leaf Extract (COLE) at (a) $254 \mathrm{~nm}$ and (b) $330 \mathrm{~nm}$. Extraction was conducted with $70 \%$ ethanol. Peaks: 1, Hydroxytyrosol; 2, Verbascoside; 3, Luteolin-7-glucoside; 4, Apigenin-7-glucoside; 5, Oleuropein; 6, Luteolin; 7, Apigenin.

caused a significant decrease of the proliferation of K562 cells in a dose dependent manner. After $72 \mathrm{~h}$ of treatment with $150 \mu \mathrm{g} / \mathrm{mL}$ of COLE, the cell proliferation was inhibited to $17 \%$ compared with the control cells (Figure 2(a)).

Observation of the morphological changes of K562 cells after treatment with the different concentrations revealed an increase in cell size especially in cells treated with $150 \mu \mathrm{g} / \mathrm{mL}$ of COLE compared with control cells which kept the same morphology and cell size (Figure 2(b)).

3.3. COLE Inhibits the Growth Rate of K562 Cells. To understand if the antiproliferative effect was led by cell death or growth inhibition, we determined the cell number and cell viability after treatment with COLE by flow cytometry. The numbers of K562 cells treated with $100 \mu \mathrm{g} / \mathrm{mL}$ and $150 \mu \mathrm{g} / \mathrm{mL}$ were significantly less than the number of control cells. K562 cells treated with COLE exhibited a slow cell growth compared to the control (Figure 3(a)).

Results (Figure 3(b)) showed that treatment with $150 \mu \mathrm{g} / \mathrm{mL}$ of COLE caused a slight decrease of the viability of K562 cells during the first 3 days with keeping more than
$80 \%$ of viable cells. Then the decrease became drastic and only $20 \%$ of live cells remain at the 6 th day of treatment by the same concentration. The viability of cells treated with $100 \mu \mathrm{g} / \mathrm{mL}$ of COLE started to decrease significantly from the 4 th day, while treatment with $50 \mu \mathrm{g} / \mathrm{mL}$ did not affect the cell viability during the whole period. Taken together, these results suggested that the antiproliferative effect of COLE at the concentrations of $100 \mu \mathrm{g} / \mathrm{mL}$ and $150 \mu \mathrm{g} / \mathrm{mL}$ might be conducted in part by inhibiting the growth rate and to a lesser extent by causing cell death.

3.4. COLE Modulates Cell Cycle Progression in K562 Cells. Since COLE reduced the growth of K562 cells, we investigated its effect on the cell cycle progression. During the 1st and 2nd day, K562 cells treated with 100 and $150 \mu \mathrm{g} / \mathrm{mL}$ were arrested at G0/G1. During the following days, results showed a significant increase of $\mathrm{G} 2 / \mathrm{M}$ population in cell treated with 100 and $150 \mu \mathrm{g} / \mathrm{mL}$ of COLE. In the case of cells treated with $150 \mu \mathrm{g} / \mathrm{mL}$ of COLE, this increase was associated with a significant decrease of G0/G1 cell population throughout the 3rd and 4th days of treatment (Table 2). 


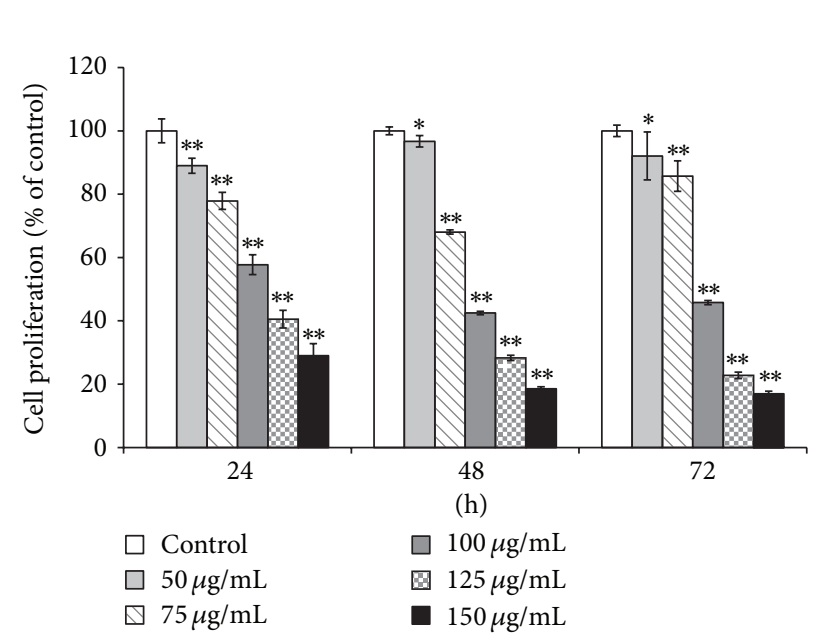

(a)
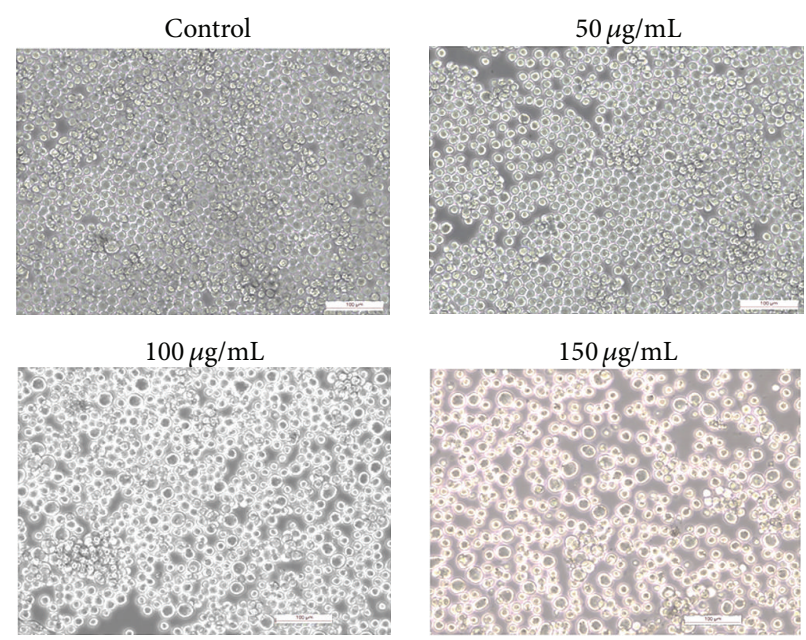

$150 \mu \mathrm{g} / \mathrm{mL}$

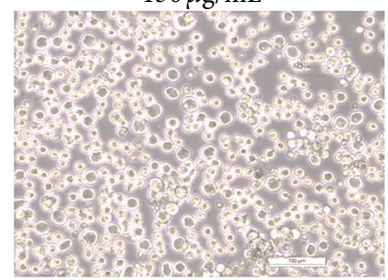

(b)

Figure 2: (a) Effect of Chemlali Olive Leaf Extract (COLE) on the proliferation of K562 cells. The cells were treated with various concentrations $(50,75,100,125$, and $150 \mu \mathrm{g} / \mathrm{mL})$ of COLE for 24,48 , and $72 \mathrm{~h}$. Cell proliferation was measured by MTT assay. Control represents cells treated with $0.3 \%$ ethanol in medium. Results are represented as the mean \pm SD of three independent experiments. *, **: significantly different from the control $(P<0.05$ and $P<0.01$, resp.). (b) Morphological observations of K562 cells after treatment with various concentrations of Chemlali Olive Leaf Extract (COLE) for $72 \mathrm{~h}$. Cells were observed under a phase contrast microscope at 100x magnification. Scale bars represent $100 \mu \mathrm{m}$.

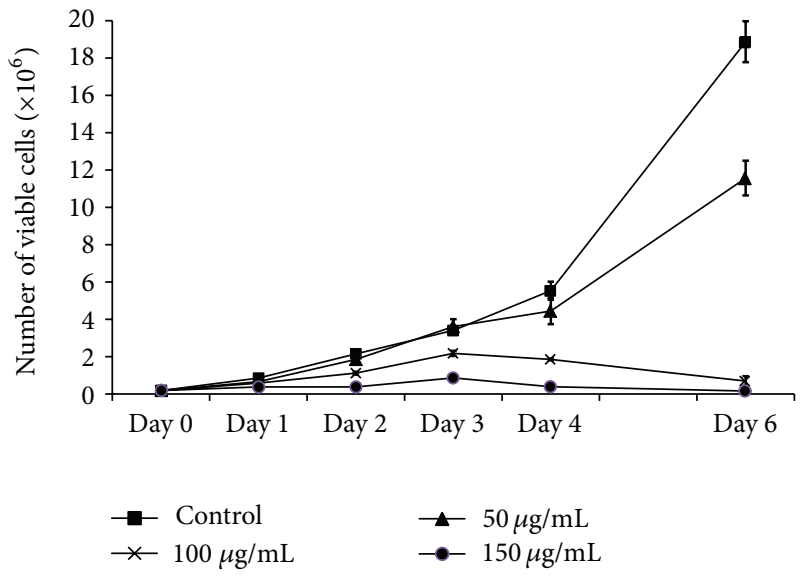

(a)

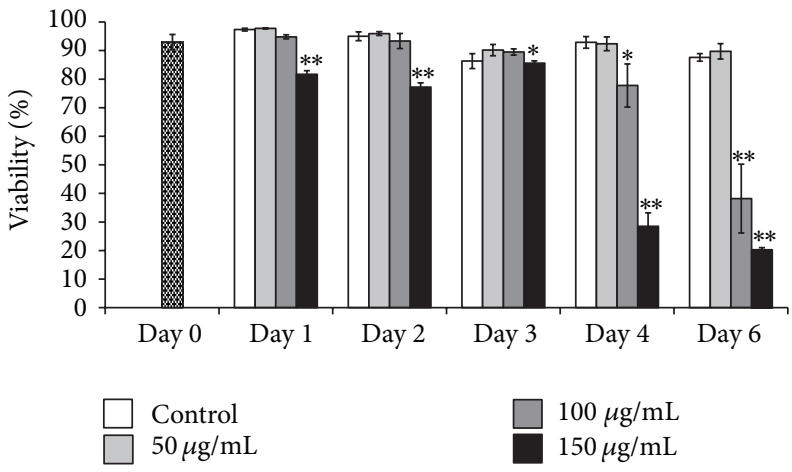

(b)

Figure 3: Effect of Chemlali Olive Leaf Extract (COLE) on the cell number and viability of K562 cells. (a) Number of viable cells after treatment with COLE after incubation up to 6 days. (b) Percentage of viability in K562 cells treated with COLE. K562 cells were treated at a final concentration of 50,100 , and $150 \mu \mathrm{g} / \mathrm{mL}$ of COLE and incubated for different periods. Cell number and cell viability were measured by flow cytometry. Control represents cells treated with $0.3 \%$ ethanol in medium. Results are represented as the mean \pm SD of three independent experiments. $*, * *$ : significantly different from the control $(P<0.05$ and $P<0.01$, resp. $)$.

3.5. COLE Induces Apoptosis in K562 Cells. The decrease in cell viability (Figure $3(\mathrm{~b})$ ) caused by COLE treatment prompted us to investigate if the extract induces apoptosis in K562 cells. Apoptosis is an important and active regulatory pathway of cell growth and proliferation resulting in some characteristic physiological changes. Among these, externalization of phosphatidylserine (PS) is easily detected by flow cytometry after binding to the labeled Annexin V. The results indicated an increase in Annexin $\mathrm{V}$ positive cells from the 1st day of incubation with $150 \mu \mathrm{g} / \mathrm{mL}$ of COLE in comparison with control cells (Figure 4). The percentage of Annexin V cells remained stable during the first 3 days of treatment with $20 \%$ of total treated cells and interestingly increased in the 4 th and 6 th days with $45 \%$ and $60 \%$, respectively. Treatment with $100 \mu \mathrm{g} / \mathrm{mL}$ caused the apparition of apoptotic cells from the 4th day of incubation with a proportion of $16.2 \%$. This population increased in the 6th day up to $26.7 \%$. No significant difference in apoptotic cells amount was detected when cells were treated with $50 \mu \mathrm{g} / \mathrm{mL}$ until 6 days of incubation. 
TABLE 2: The distribution of cell cycle in K562 cells treated with Chemlali Olive Leaf Extract (COLE).

\begin{tabular}{lccccc}
\hline & & Day 1 & Day 2 & Day 3 & Day 4 \\
\hline \multirow{3}{*}{ G0/G1 } & Control & $27.63 \pm 2.90$ & $24.50 \pm 0.45$ & $31.36 \pm 1.85$ & $29.83 \pm 3.52$ \\
& $100 \mu \mathrm{g} / \mathrm{mL}$ & $27.36 \pm 4.07$ & $22.56 \pm 2.67$ & $27.76 \pm 2.09$ & $23.45 \pm 3.81$ \\
& $150 \mu \mathrm{g} / \mathrm{mL}$ & $39.80 \pm 2.26^{*}$ & $31.01 \pm 1.3^{* *}$ & $20.96 \pm 2.78^{* *}$ & $12.43 \pm 0.64^{* *}$ \\
\hline \multirow{3}{S}{} & Control & $22.07 \pm 1.15$ & $21.07 \pm 1.33$ & $17.70 \pm 2.1$ & $20.00 \pm 1.6$ \\
& $100 \mu \mathrm{g} / \mathrm{mL}$ & $27.69 \pm 2.59^{*}$ & $22.35 \pm 1.83$ & $18.93 \pm 0.72$ & $16.15 \pm 0.73^{*}$ \\
& $150 \mu \mathrm{g} / \mathrm{mL}$ & $14.65 \pm 3.58^{*}$ & $24.54 \pm 0.6^{*}$ & $18.49 \pm 3.47$ & $16.88 \pm 2.59$ \\
\hline \multirow{3}{*}{$\mathrm{G} 2 / \mathrm{M}$} & $\mathrm{Control}$ & $33.57 \pm 0.98$ & $30.20 \pm 1.44$ & $27.93 \pm 1.36$ & $28.60 \pm 0.7$ \\
& $100 \mu \mathrm{g} / \mathrm{mL}$ & $24.41 \pm 2.27^{* *}$ & $36.97 \pm 1.6^{* *}$ & $32.47 \pm 1.1^{*}$ & $36.11 \pm 2.64^{* *}$ \\
& $150 \mu \mathrm{g} / \mathrm{mL}$ & $18.93 \pm 0.54^{* *}$ & $27.72 \pm 2.07$ & $37.25 \pm 2.1^{* *}$ & $34.00 \pm 1.83^{* *}$ \\
\hline
\end{tabular}

Results are represented as the means \pm SD of three independent experiments.

* and * mean that difference between control and treated cells in each phase (G0/G1, S and G2/M) is statistically significant at $P<0.05$ and $P<0.01$, respectively.

3.6. Impact of COLE on the Differentiation Capacity of K562 Cells. The reduction in cell growth, as well as the morphological changes observed in COLE treated cells, led us to think about the differentiation assessment. K562 cells are pluripotent malignant cells that spontaneously differentiate along erythroid, macrophage, and megakaryocyte lineages [22]. Treated cells were harvested and analyzed for the expression of lineage differentiation markers. The analysis was performed by flow cytometry at different days on the monocyte/macrophage marker CD14, on the granulocyte marker CD11b, on the erythrocyte marker GPA and on the megakaryocyte marker CD41. The results showed a significant increase in the expression of CD14 marker from day 1 until day 6 in the cells treated with $150 \mu \mathrm{g} / \mathrm{mL}$, suggesting the commitment of K562 cells to the monocyte/macrophage lineage (Figure 5(a)). A slight increase of the expression of CD11b was also detected at this concentration (Figure 5(b)). Treatment with $100 \mu \mathrm{g} / \mathrm{mL}$ showed a gain in the expression of CD14 on the 1st and 2nd day and an augmentation of CD11b expression from the $3 \mathrm{rd}$ day of treatment. Treatment with $50 \mu \mathrm{g} / \mathrm{mL}$ did not show any significant effect on the differentiation markers CD14 and CD11b. Even after 6 days of treatment with $150 \mu \mathrm{g} / \mathrm{mL}$ of COLE, we could not detect the erythroid marker at all the tested concentrations (Figure 5(d)). However, an instant increase in the megakaryocytic marker was detected on the 1st day of treatment, followed by a drastic decrease, lower than the control, during the following days (Figure 5(c)).

3.7. Gene Expression Profile of COLE Treated K562 Cells. To further elucidate the mechanism by which COLE induces apoptosis and differentiation of $\mathrm{K} 562$ cells, we investigated the changes in gene expression profiles in treated cells using HG219 GeneChip array. Microarray analysis was performed on K562 cells at the 3rd day of treatment based on the observation that such timing generated a significant expression of the differentiation markers. Genes with more than 1.5-fold change in expression levels between control and $150 \mu \mathrm{g} / \mathrm{mL}$ of COLE treated cells were classified into categories according to the cell biological processes. According to the GO analysis

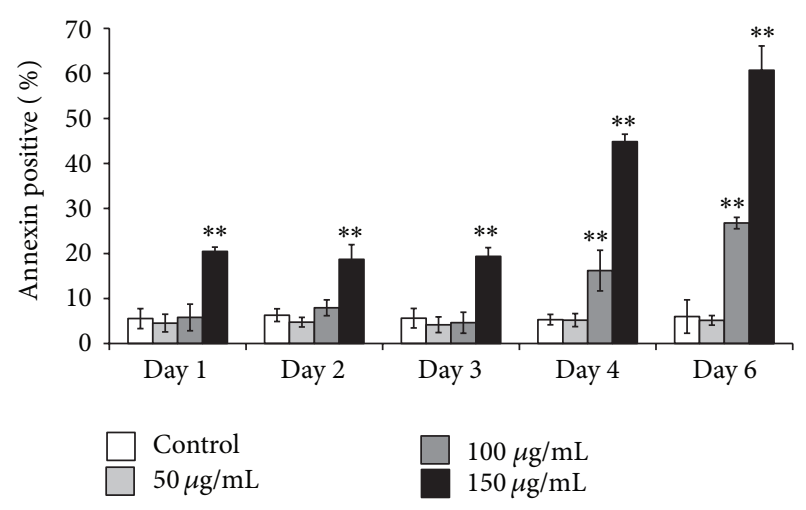

FIGURE 4: Induction of apoptosis in K562 cells treated with Chemlali Olive Leaf Extract (COLE). Cells were treated with 50, 100, and $150 \mu \mathrm{g} / \mathrm{mL}$ of COLE and incubated for different time. At the indicated time, K562 cells were stained with Annexin V and analyzed by flow cytometry. Control represents cells treated with $0.3 \%$ ethanol in medium. Results are represented as the mean $\pm \mathrm{SD}$ of three independent experiments. $*$, $* *$ : significantly different from the control $(P<0.05$ and $P<0.01$, resp. $)$.

results (Tables S1 and S2 in Supplementary Material available online at http://dx.doi.org/10.1155/2014/927619), COLE treatment induced the upregulation of genes involved in hematopoiesis such as CTNNB1, SH2B3, CIAPIN1, RPA1, and genes implicated in cell differentiation and its regulation such as MCL1, CTNNB1, and CCNE1. Interestingly, genes related to myeloid cell differentiation, such as IFI16, ACIN1, and CASP8, and particularly genes engaged in monocyte differentiation were represented in the upregulated categories. Moreover, an increased expression of genes involved in chemotaxis such as NUP85, HRAS, IL8, CXCL2, and CXCL3 and genes related to cytokine production was also detected. Among upregulated genes AP1G1, RABEP1, RAB5C, RAB21, EPS15L1, and $C O R O 1 C$ were also found involved in the process of endocytosis and phagocytosis as well as genes related to protein transport and genes implicated in cell adhesion such as ICAM3, HSPB11, and PNN.

Conversely, the erythrocyte differentiation categories were represented in the list of the decreased genes (Table S2) 


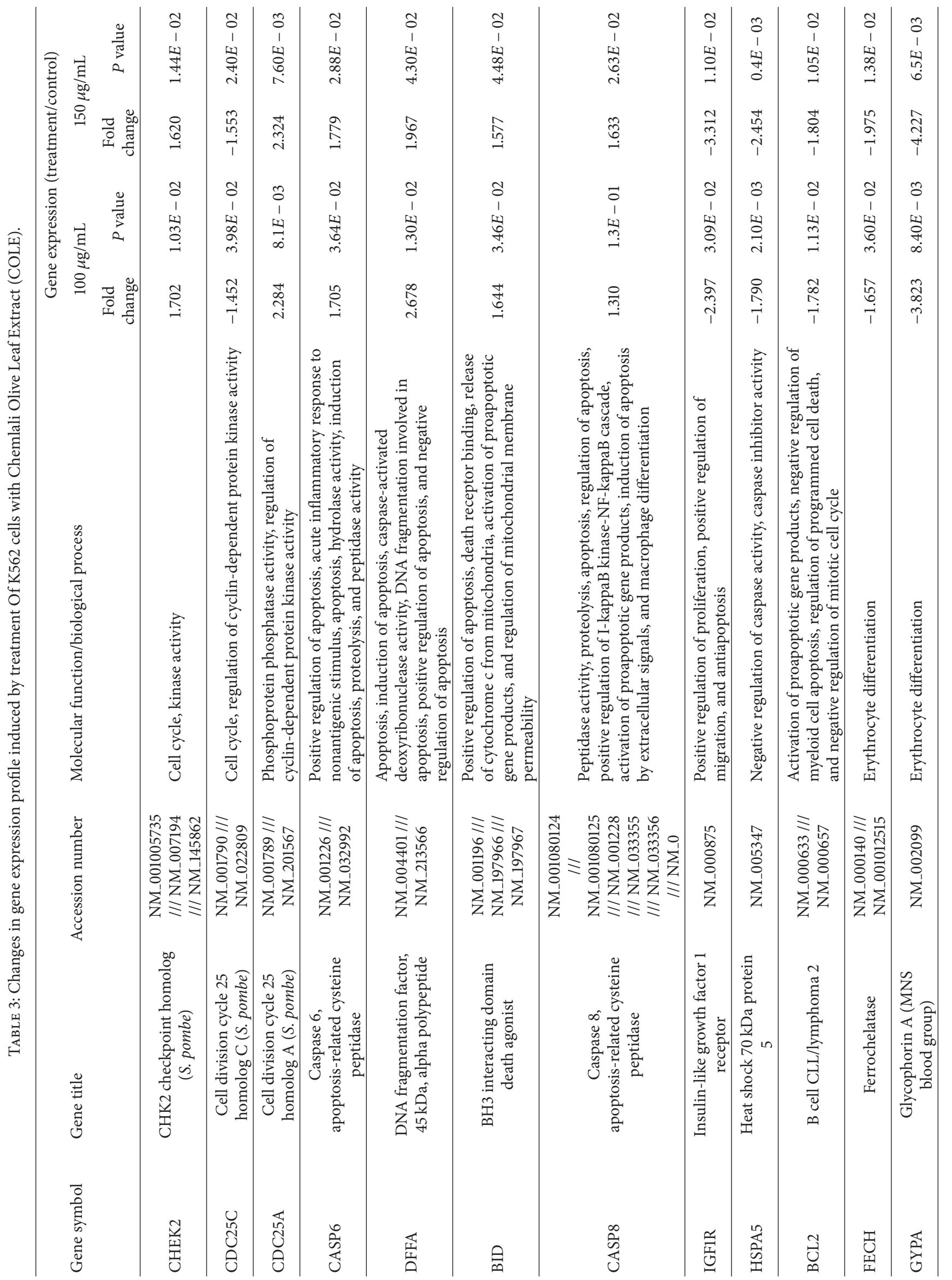




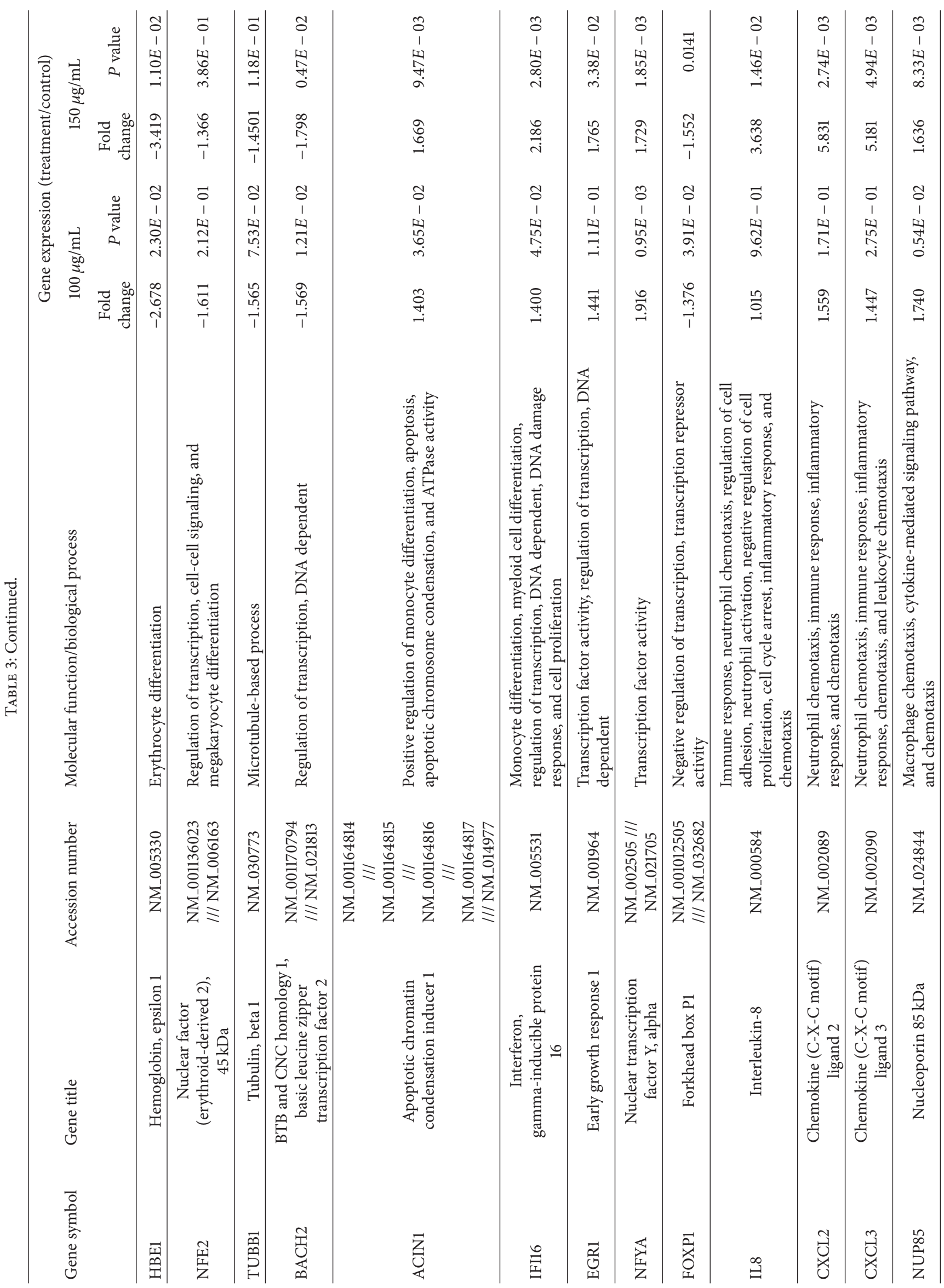




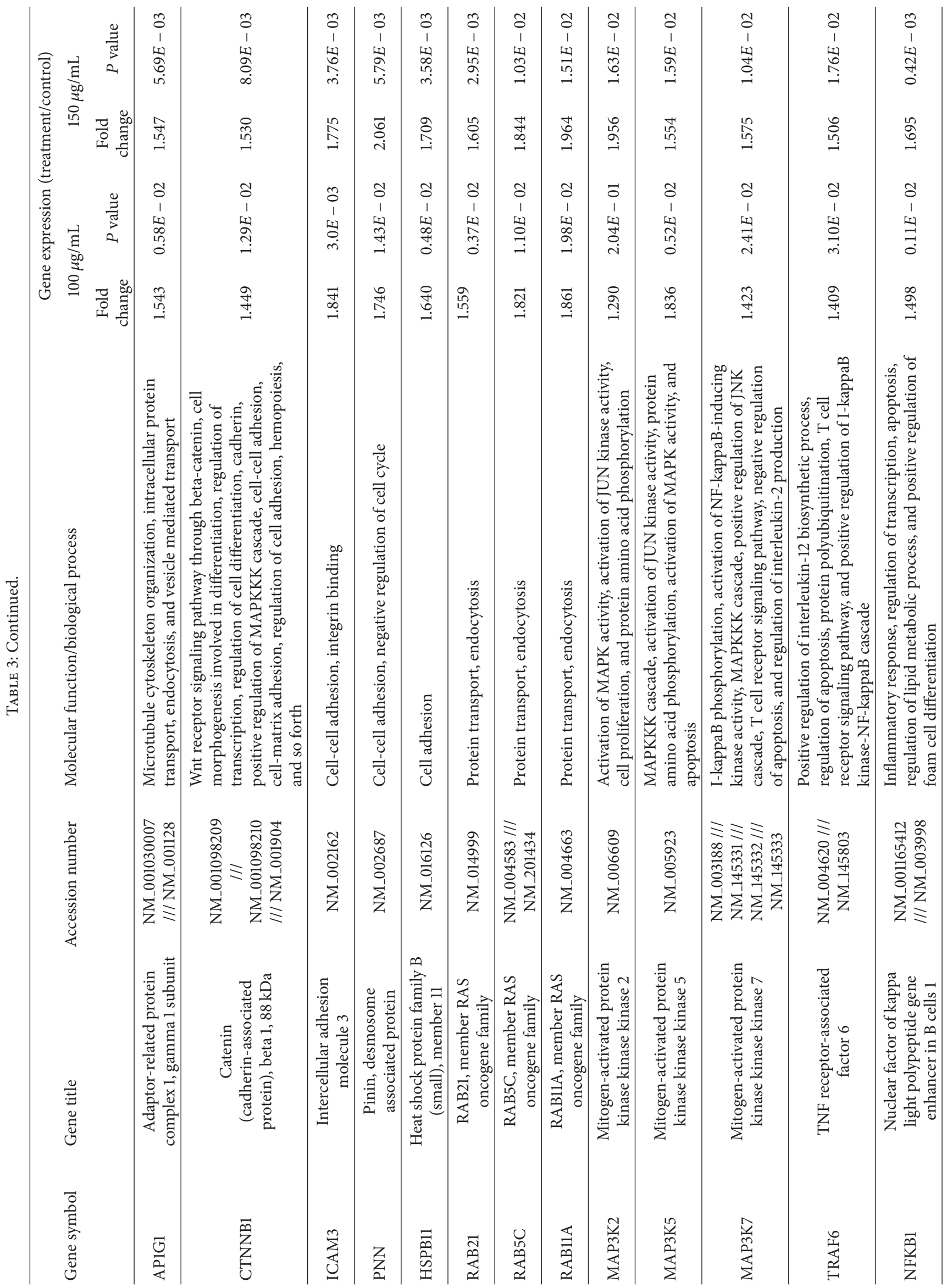




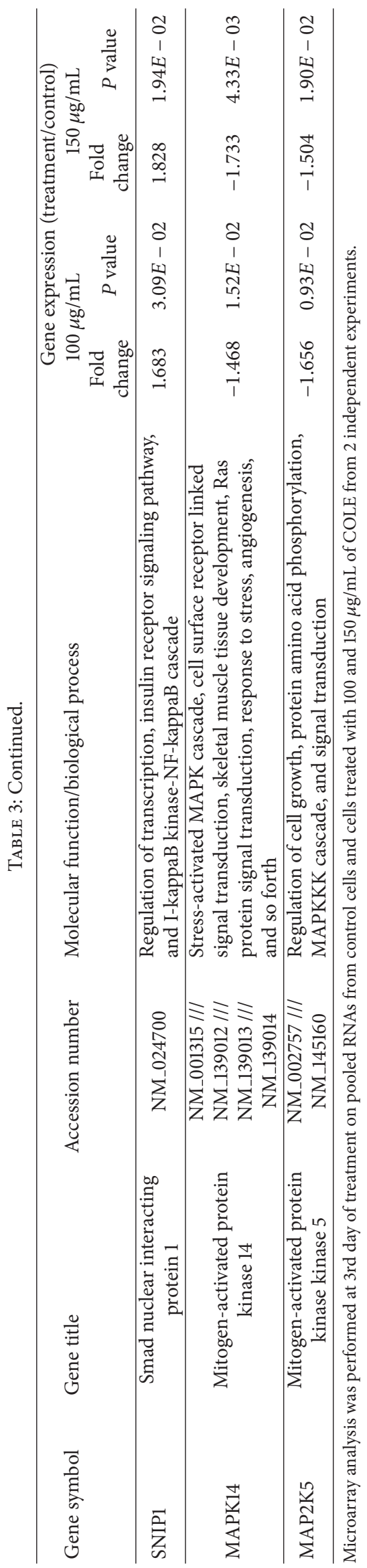



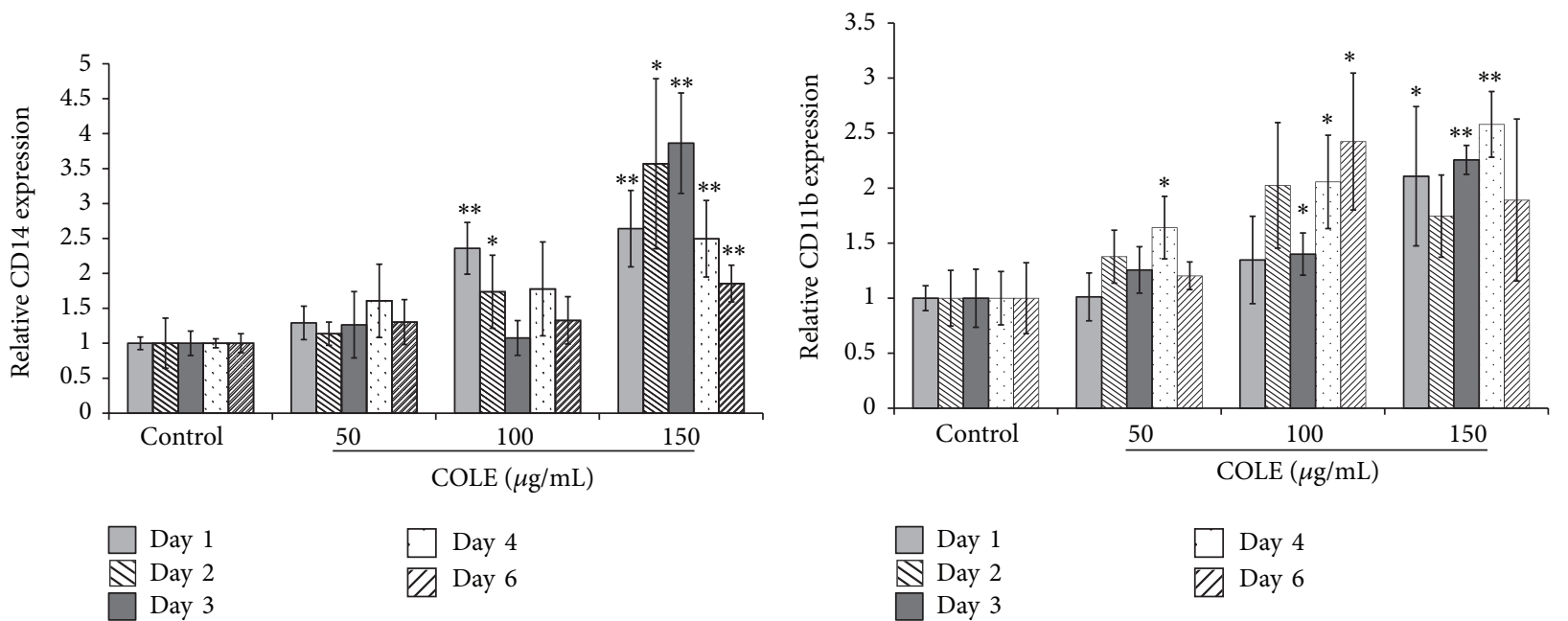

(a)

(b)

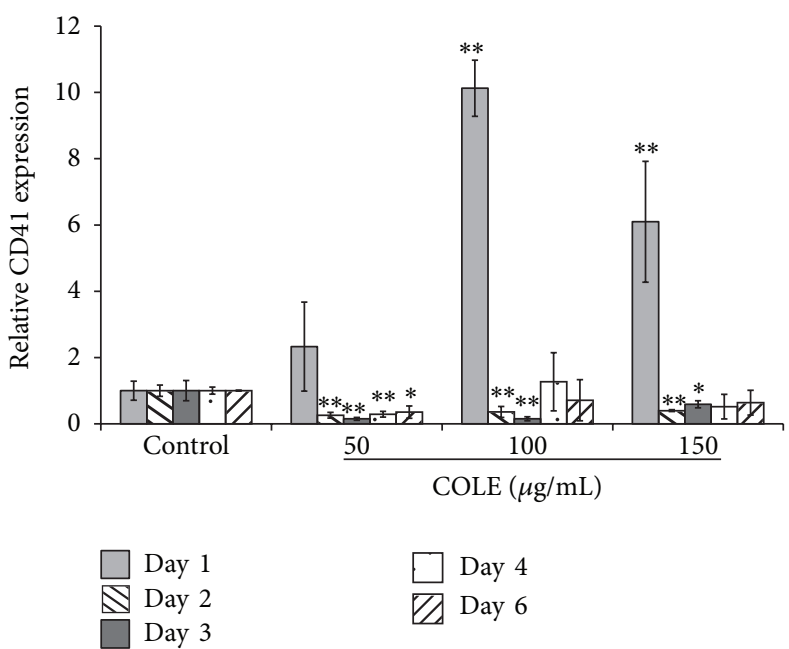

(c)

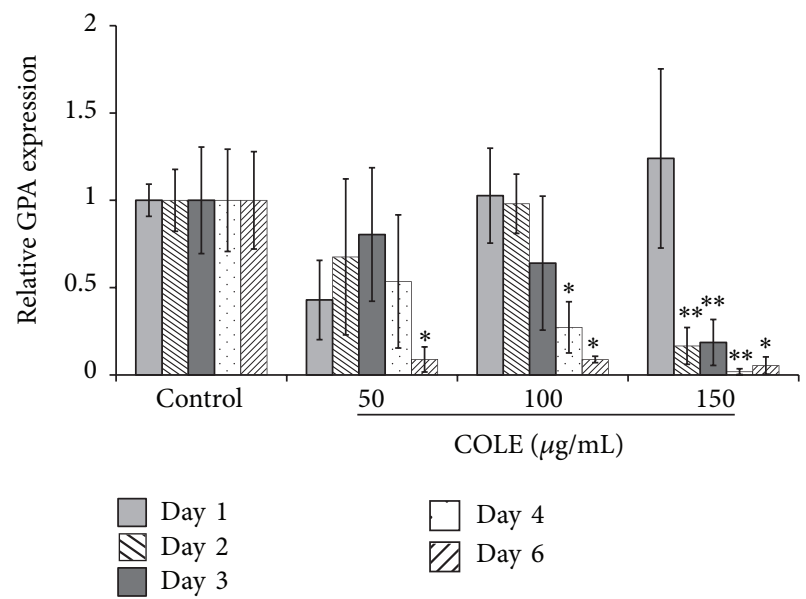

(d)

FiguRE 5: Expression of differentiation markers on K562 cells treated with Chemlali Olive Leaf Extract (COLE) up to 6 days. Cells were treated with 50,100, and $150 \mu \mathrm{g} / \mathrm{mL}$ of COLE and incubated for different periods. Control cells were treated with ethanol at a final concentration of $0.3 \%$. Expression of cell surface markers was detected by flow cytometry. (a) Expression of CD14 (monocyte/macrophage specific marker). (b) Expression of CD11b (granulocyte/monocyte specific marker). (c) Expression of CD41 (megakaryocyte specific marker). (d) Expression of glycophorin A (GPA) (erythrocyte specific marker). Results are represented as the mean \pm SD of three independent experiments. $*, * *$ : significantly different from the control at $P<0.05$ and $P<0.01$, respectively.

including GYPA, HBE1, FECH, and ALAS2, which is consistent with the decreased expression of erythrocyte differentiation marker in the flow cytometry results (Figure 5(d)).

Analysis of the microarray data showed the upregulation of several proapoptotic genes and genes involved in the regulation of mitochondrial membrane permeability such as CASP6, CASP8, DFFA, and BID. On the other hand,expression of genes negatively regulating the apoptosis and those inhibiting the caspase activity was significantly decreased such as IGF1R, HSPA5, and BCL2.

Among the upregulated genes, we found those related to the NF-kappaB cascade as well as to the MAPKKK cascade and the Wnt receptor signaling pathway.

Categories related to cell cycle regulation and cell proliferation were represented by both upregulated and downregulated genes. Finally, some transcription factors were also downregulated, such as FOXP1, whereas others were upregulated like EGR1 and NFYA.

The list of selected genes is presented in Table 3. From this list, it is clear that the differentially expressed genes after treatment with 100 and $150 \mu \mathrm{g} / \mathrm{mL}$ have mostly the same tendency, which could validate the obtained results. 


\section{Discussion}

Previous reports had indicated that olive leaf extract induces apoptosis in the human leukemic cell lines HL-60 and Jurkat cells $[13,21]$. In this study we give evidence that COLE exhibits its antileukemia effect by both inducing apoptosis and promoting differentiation of the multipotent human leukemia K562 cells.

Induction of differentiation, as well as apoptosis, has been frequently reported to be associated with a loss of proliferative capacity of the cells. It has been reported that olive leaf extract inhibits the proliferation of some cancer cell lines such as B16 melanoma cells, HL-60 leukemia cells, the breast cancer MCF-7 cells, and the glioblastoma cells [12, 25-27]. Our results indicate that COLE inhibits the proliferation of $\mathrm{K} 562$ cells in a dose dependent manner (Figure 2(a)). However, despite the drastic decrease in cell proliferation, the viability of cells treated with the highest concentration of COLE $(150 \mu \mathrm{g} / \mathrm{mL})$ remains relatively high $(80 \%)$ for up to 3 days of treatment (Figure 3(b)).

Since it is well established that the arrest of the cell cycle progression allows the cells to follow other processes such as apoptosis and differentiation, we then explored the effect of COLE on the cell cycle distribution (Table 2). Olive leaf extract has been shown to cause cell cycle arrest at G0/G1 phase in both the breast cancer MCF-7 cells and the melanoma B16 cells [12, 25]. However, the treatment times applied in both of these studies were limited to $48 \mathrm{~h}$ and $18 \mathrm{~h}$, respectively. In this study, COLE treated cells were arrested at G0/G1 on the 1st and 2nd day of treatment, which is consistent with the reported studies. Prolonged incubation with COLE showed an arrest of cell cycle at G2/M phase (3rd and 4th day of incubation). The microarray analysis, performed for the 3rd day of treatment, revealed a significant increase of CHEK2 gene expression in COLE treated cells. The encoded protein regulates the cell cycle checkpoint arrest through the inhibition of the activity of CDC25A, CDC25B, and CDC25C [28]. CDC25 proteins trigger the entry into mitosis at different points of the cell cycle by activating the Cdk-cyclin complexes. CDC25A acts early in the cell cycle, regulating the G1/S transition, whereas CDC25B and CDC25C act at G2/M [29]. Interestingly, our results showed a decrease in the expression of CDC25C gene in COLE treated cells associated with an increase in the expression of $C D C 25 A$, which may explain the cell cycle arrest at G2/M phase observed at the 3rd day of treatment with COLE.

Treatment with COLE increased the expression of CD14 on the cell surface of treated cells indicating the differentiation of K562 cells toward the mono-/macrophage lineage (Figure 5(a)). The increase in the percentage of cells positive for CD11b (Figure 5(b)) confirms this hypothesis. In fact, CD11b is expressed on both monocytes and granulocytes. Thus, together with the increase of CD14 expression, the expression of CD11b suggests that treatment with COLE promotes the commitment of K562 cells into the monocyte/macrophage lineage at the expense of the granulocytic differentiation. The instant increase of the expression of CD41 on the 1st day of treatment and its absence during the following days (Figure 5(c)) could be consistent with monocyte differentiation instead of megakaryocyte differentiation since it has been reported that $\alpha \mathrm{IIb}$ promoter, which initiates the transcription of CD41, is transcriptionally active in pluripotent myeloid progenitors, in early stages of erythropoiesis, and all along the megakaryocytic differentiation as well as, to a lesser extent, in the early stages of myelomonocytic differentiation and the late stages of erythropoiesis [30]. This instant increase could be also explained by the phenomenon of lineage conversion, where some hematopoietic progenitors can be converted into lineages other than their own by the ectopic expression of some transcription factors [31]. In this regard, it was previously reported that common lymphoid progenitors, megakaryocyte erythroid progenitors, early B cells, and early $\mathrm{T}$ cells could be converted to the granulocyte/monocyte lineage by the induction of $\mathrm{C} / \mathrm{EBP} \alpha$ activity [32]. Microarray results support the absence of megakaryocyte differentiation in the 3rd day of treatment. In fact, data showed a decrease in the expression of genes related to megakaryopoiesis such as the essential regulator of platelet release NFE2 and its main candidate target gene TUBB1 (encoding the megakaryocyte and platelet specific isoform of $\beta$-tubulin ( $\beta 1)$ ) [33] as well as the $B A C H 2$ transcription factor reported to be induced during megakaryocyte differentiation [34].

Interestingly, results of microarray analysis (Table 3) showed the upregulation of several genes already reported as key players in monocyte/macrophage differentiation in the COLE treated cells. Among these genes, the expression of IFI16 was markedly increased. Constitutively expressed in lymphoid cells, IFI16 was shown to be associated with the differentiation of human myeloid cells in response to interferon gamma [35]. Moreover, IFI16 has been selectively expressed during the differentiation of myeloid progenitor cells along monocytic lineage, while it is downregulated during the commitment toward the granulocytic or erythroid lineage, suggesting its potential involvement in the differentiation and maturation of the monocytic lineage [36, 37]. Gene encoding for EGR-1, a positive modulator of macrophage differentiation, was also significantly upregulated. EGR-1 is known to dictate development of myeloid progenitors along the macrophage lineage at the expense of development along other lineages [38, 39]. Dauffy et al., [40], reported that IFI16-enforced expression in myeloid progenitors induced the expression of EGR-1 and conducted the macrophage differentiation in the absence of the macrophage colony stimulating factor (M-CSF). This suggests that EGR-1 could be regulated by the expression of IFI16. Treatment with COLE increased as well the expression of NFYA encoding the A subunit of the nuclear transcription factor $\mathrm{Y}$ whose synthesis was previously reported during the terminal differentiation of monocytes to macrophages [38, 41]. The downregulation of FOXP1 in COLE treated K562 cells is consistent with monocyte/macrophage differentiation since it has been demonstrated that the expression of FOXP1 was markedly decreased in monocyte-induced differentiation of HL-60 cells as well as in human peripheral blood monocytes and 
that the overexpression of FOXP1 prevented the morphologic macrophage-like differentiation $[42,43]$.

Monocytes and macrophages have several functional characteristics including cell adhesion, migration, chemotaxis, and phagocytic activity. Interestingly, an enhanced expression of the chemokines genes CXCL8 (IL8), CXCL2, and $C X C L 3$ was found in COLE treated cells. IL- 8 production has been observed in vitro in a wide variety of cells including monocytes, T lymphocytes, neutrophils, vascular endothelial cells, dermal fibroblasts, keratinocytes, hepatocytes, and human gastric cancer cells, while the production of CXCL2 and CXCL3 was only described in monocytes, fibroblasts, and endothelial cells $[44,45]$. Another gene related to chemotaxis was upregulated: NUP85 which is an essential component of the nuclear pore complex and was reported to be involved in CCR2-mediated chemotaxis of monocytes [46].

COLE treatment also enhanced the expression of some genes related to phagocytosis: AP1G1 and Rab proteins related genes. AP1G1 is a subunit of clathrin-associated adaptor protein complex 1 whose role has been recently highlighted for efficient phagocytosis at an early stage of phagosome formation since it participates in the extension of the phagocytic cup $[47,48]$. The small GTPases Rab are key regulators of intracellular membrane trafficking. Recent studies have demonstrated that several RAB proteins play an important role in phagocytosis. RAB proteins such as RAB11, Rab5, and $\mathrm{Rab} 21$ participate in the phagosome formation and maturation and are necessary for the phagocytic activity [48-51].

Consistently with the increase in Annexin V positive cells (Figure 4), treatment with COLE upregulated some proapoptotic genes such as CASP6, CASP8, DFFA, and BID and downregulated the apoptosis suppressor BCL2 as well as the caspase inhibitors genes (Table 3 ). Olive leaf was previously shown to induce morphological changes that are characteristic of apoptosis in leukemia cells, but the mechanisms underlying this effect were not well investigated $[13,21]$. The increase in the proportion of apoptotic cells observed from the 4th day of treatment with COLE could be explained by the programmed death of the fully differentiated cells (Figure 4). In fact, this increase was accompanied by an important decrease in cell viability as well as a diminution in CD14 expression (Figures 3(b) and 5(a)). Elsewhere, it is well established that, in hematopoietic tissues, apoptosis is coupled to terminal differentiation of myeloid progenitors, even though the mechanism responsible for the activation of apoptosis during myeloid maturation is still poorly understood $[52,53]$. It is also noteworthy to mention that several reports have highlighted the role of caspases in the terminal differentiation of a variety of cell types [54]. One example is the differentiation of human blood monocytes into macrophages, a process that is blocked by synthetic caspase inhibitors [55]. It has been also reported that caspase 8 deletion in bone-marrow cells resulted in arrest of hemopoietic progenitor functioning and that its deletion in cells of the myelomonocytic lineage led to the arrest of differentiation into macrophages and consequently to cell death [56].

Among the differentially expressed genes in COLE treated cells (Table 3 ), genes encoding the mitogen-activated protein kinase kinase kinases (MAPKKKs) MAP3K2, MAP3K5, and MAP3K7 were highly expressed, while MAP2K5 and MAPK14/p38- $\alpha$ were downregulated. The MAPKKKs act at the upstream of the MAP kinase cascade which regulates important cellular processes such as gene expression, cell proliferation, differentiation, cell survival, and death. The MAP3K5 activates the c-Jun N-terminal kinase (JNK) and p38 mitogen-activated protein kinases [57] while the MAP3K2 is reported to preferentially activate JNK $[58,59]$. However, the significant decrease in the MAPK14/p38- $\alpha$ may suggest that the effect of COLE on K562 cells is likely to be mediated by the JNK MAPKs, rather than the p38 MAPKs. JNK plays an important role in apoptosis pathways weather by activating proapoptotic or antiapoptotic genes. Particularly, it was shown that prolonged, but not transient, JNK activation promotes the cell death [60]. Our results showed that JKAMP gene which encodes for, a membrane-anchored regulator of the duration of JNK1 activity, was upregulated $(1.54 \pm 0.051)$. The elevated expression of JKAMP, as reported by Kadoya et al., [61], results in sustained JNK activity. These findings may indicate the potential role of JNK pathway in the COLE-induced apoptosis in K562 cells.

Thanks to their large regulatory domains, some MAPKKKs can interact with upstream regulators, have functions such as ubiquitylation, and be activated by relief of autoinhibition and oligomerization [62]. In this context, MAP3K2 has been reported to play an important role in NF-kappaB signaling pathway by activating the I-kappaB kinases which in turn phosphorylate the inhibitory factors of the nuclear factor kappaB (NF-kappaB) resulting in their rapid ubiquitination and the liberation of NF-kappaB complex which translocate from the cytoplasm to the nucleus [63]. MAP3K7, in association with other proteins, could also be required for the activation of NF-kappaB. According to the GO analysis (Table S1), COLE treatment upregulated genes implicated in NF-kappaB-related categories such as positive regulation of NF-kappaB transcription factor activity, I-kappaB kinaseNF-kappaB cascade and its positive regulation, and I-kappaB phosphorylation. Genes encoding the signal transducers in the NF-kappaB pathway, TRAF5, and TRAF6, as well as the activator of NF-kappaB signaling SNIP1, were upregulated. Interestingly, an increased expression of NFKB1 gene, encoding for the precursor of the mature NF-kappaB p50, was detected in COLE treated cells compared to untreated K562 cells. NFKB is well recognized as a central activator of the antiapoptotic cascades in response to external stimuli or intrinsic immune reactions, and its prosurvival activity has been implicated in a variety of biological processes $[60,64]$. In the B cell lineage, the activity of NF- $\kappa \mathrm{B}$ is required for the completion of various developmental stages including differentiation and the response of these cells to antigens [65]. NF-kappaB also plays an important role in the survival and development of T cells [66] and has been recently reported to mediate the differentiation of mesenchymal stem cells [67].

Several studies have demonstrated a crosstalk between the NF-kappaB and JNK pathways seen as an inhibitory effect of NF-kappaB on apoptosis through the suppression of JNK activity and that this suppressive effect may occur 
through different mechanisms [60]. This suggests that the balance between JNK and NF-kappaB activities is crucial to determine the cell fate, survival or death. We hypothesize here that COLE-induced apoptosis or differentiation is likely to be determined by the crosstalk between these two pathways in K562 cells. Further investigations regarding protein expression and activity are needed to confirm these findings.

\section{Conclusions}

Our study demonstrates for the first time that olive leaf extract exhibits an antileukemia effect on the human chronic myeloid leukemia cells. Olive leaf extract was shown to inhibit the proliferation of K562 cells by inducing cell cycle arrest, apoptosis, and differentiation toward the monocyte lineage. The induced expression of molecules involved in differentiation toward the monocyte/macrophage lineage as well as molecules related to apoptosis and cell cycle regulation confirmed these findings and provides insights into the mechanism by which olive leaf exhibits its antileukemia effect.

\section{Conflict of Interests}

The authors declare that there is no conflict of interests regarding the publication of this paper.

\section{Acknowledgment}

This research was supported by the JICA-JST Science and Technology Research Partnership for Sustainable Development (SATREPS) Project: "Valorization of Bio-Resources in Semi-Arid and Arid Land for Regional Development."

\section{References}

[1] M. Leszczyniecka, T. Roberts, P. Dent, S. Grant, and P. B. Fisher, "Differentiation therapy of human cancer: basic science and clinical applications," Pharmacology and Therapeutics, vol. 90, no. 2-3, pp. 105-156, 2001.

[2] A. I. Spira and M. A. Carducci, "Differentiation therapy," Current Opinion in Pharmacology, vol. 3, no. 4, pp. 338-343, 2003.

[3] S. Nobili, D. Lippi, E. Witort et al., "Natural compounds for cancer treatment and prevention," Pharmacological Research, vol. 59, no. 6, pp. 365-378, 2009.

[4] S. Ramos, "Effects of dietary flavonoids on apoptotic pathways related to cancer chemoprevention," Journal of Nutritional Biochemistry, vol. 18, no. 7, pp. 427-442, 2007.

[5] V. Hajhashemi, G. Vaseghi, M. Pourfarzam, and A. Abdollahi, "Are antioxidants helpful for disease prevention?" Research in Pharmaceutical Sciences, vol. 5, no. 1, pp. 1-8, 2010.

[6] M. Bouaziz and S. Sayadi, "Isolation and evaluation of antioxidants from leaves of a Tunisian cultivar olive tree," European Journal of Lipid Science and Technology, vol. 107, no. 7-8, pp. 497504, 2005.

[7] A. P. Pereira, I. C. F. R. Ferreira, F. Marcelino et al., "Phenolic compounds and antimicrobial activity of olive (Olea europaea L. Cv. Cobrançosa) leaves," Molecules, vol. 12, no. 5, pp. 11531162, 2007.
[8] L. I. Somova, F. O. Shode, P. Ramnanan, and A. Nadar, "Antihypertensive, antiatherosclerotic and antioxidant activity of triterpenoids isolated from Olea europaea, subspecies africana leaves," Journal of Ethnopharmacology, vol. 84, no. 2-3, pp. 299305, 2003.

[9] V. Micol, N. Caturla, L. Pérez-Fons, V. Más, L. Pérez, and A. Estepa, "The olive leaf extract exhibits antiviral activity against viral haemorrhagic septicaemia rhabdovirus (VHSV)," Antiviral Research, vol. 66, no. 2-3, pp. 129-136, 2005.

[10] J. Wainstein, T. Ganz, M. Boaz et al., "Olive leaf extract as a hypoglycemic agent in both human diabetic subjects and in rats," Journal of Medicinal Food, vol. 15, no. 7, pp. 605-610, 2012.

[11] L. Seddik, T. M. Bah, A. Aoues, M. Slimani, and M. Benderdour, "Elucidation of mechanisms underlying the protective effects of olive leaf extract against lead-induced neurotoxicity in Wistar rats," Journal of Toxicological Sciences, vol. 36, no. 6, pp. 797809, 2011.

[12] Z. Bouallagui, J. Han, H. Isoda, and S. Sayadi, "Hydroxytyrosol rich extract from olive leaves modulates cell cycle progression in MCF-7 human breast cancer cells," Food and Chemical Toxicology, vol. 49, no. 1, pp. 179-184, 2011.

[13] R. Fares, S. Bazzi, S. E. Baydoun, and R. M. Abdel-Massih, “The antioxidant and anti-proliferative activity of the Lebanese Olea europaea extract," Plant Foods for Human Nutrition, vol. 66, no. 1, pp. 58-63, 2011.

[14] V. Goulas, V. Exarchou, A. N. Troganis et al., "Phytochemicals in olive-leaf extracts and their antiproliferative activity against cancer and endothelial cells," Molecular Nutrition and Food Research, vol. 53, no. 5, pp. 600-608, 2009.

[15] M. de Bock, E. B. Thorstensen, J. G. Derraik, H. V. Henderson, P. L. Hofman, and W. S. Cutfield, "Human absorption and metabolism of oleuropein and hydroxytyrosol ingested as olive (Olea europaea L.) leaf extract," Molecular Nutrition and Food Research, vol. 57, no. 11, pp. 2079-2085, 2013.

[16] R. Briante, M. Patumi, S. Terenziani, E. Bismuto, F. Febbraio, and R. Nucci, "Olea europaea L. leaf extract and derivatives: antioxidant properties," Journal of Agricultural and Food Chemistry, vol. 50, no. 17, pp. 4934-4940, 2002.

[17] O. Benavente-García, J. Castillo, J. Lorente, A. Ortuño, and J. A. Del Rio, "Antioxidant activity of phenolics extracted from Olea europaea L. leaves," Food Chemistry, vol. 68, no. 4, pp. 457-462, 2000.

[18] S. H. Omar, "Oleuropein in olive and its pharmacological effects," Scientia Pharmaceutica, vol. 78, no. 2, pp. 133-154, 2010.

[19] H. Jemai, M. Bouaziz, I. Fki, A. El Feki, and S. Sayadi, "Hypolipidimic and antioxidant activities of oleuropein and its hydrolysis derivative-rich extracts from Chemlali olive leaves," Chemico-Biological Interactions, vol. 176, no. 2-3, pp. 88-98, 2008.

[20] R. García-Villalba, M. Larrosa, S. Possemiers, F. A. TomásBarberán, and J. C. Espín, "Bioavailability of phenolics from an oleuropein-rich olive (Olea europaea) leaf extract and its acute effect on plasma antioxidant status: comparison between preand postmenopausal women," European Journal of Nutrition, 2013.

[21] J. Anter, Z. Fernández-Bedmar, M. Villatoro-Pulido et al., "A pilot study on the DNA-protective, cytotoxic, and apoptosisinducing properties of olive-leaf extracts," Mutation Research, vol. 723, no. 2, pp. 165-170, 2011.

[22] J. A. Sutherland, A. R. Turner, and P. Mannoni, "Differentiation of K562 leukemia cells along erythroid, macrophage, 
and megakaryocyte lineages," Journal of Biological Response Modifiers, vol. 5, no. 3, pp. 250-262, 1986.

[23] K. Schwenke, H.-P. Peterson, K.-H. Wangenheim, and L. E. Feinendegen, "Induction of differentiation in erythroleukemic K562 cells by $\gamma$-irradiation," Leukemia Research, vol. 19, no. 12, pp. 955-961, 1995.

[24] V. N. Enujiugha, J. Y. Talabi, S. A. Malomo, and A. I. Olagunju, "DPPH radical scavenging capacity of phenolic extracts from African Yam Bean (Sphenostylis stenocarpa)," Food and Nutrition Sciences, vol. 3, pp. 7-13, 2012.

[25] S. A. Mijatovic, G. S. Timotijevic, D. M. Miljkovic et al., "Multiple antimelanoma potential of dry olive leaf extract," International Journal of Cancer, vol. 128, no. 8, pp. 1955-1965, 2011.

[26] L. Abaza, T. P. N. Talorete, P. Yamada, Y. Kurita, M. Zarrouk, and H. Isoda, "Induction of growth inhibition and differentiation of human leukemia HL-60 cells by a Tunisian Gerboui olive leaf extract," Bioscience, Biotechnology and Biochemistry, vol. 71, no. 5, pp. 1306-1312, 2007.

[27] B. Tunca, G. Tezcan, G. Cecener et al., "Olea europea leaf extract alters microRNA expression in human glioblastoma cells," Journal of Cancer Research and Clinical Oncology, vol. 138, no. 11, pp. 1831-1844, 2012.

[28] S. Matsuoka, M. Huang, and S. J. Elledge, "Linkage of ATM to cell cycle regulation by the Chk2 protein kinase," Science, vol. 282, no. 5395, pp. 1893-1897, 1998.

[29] C. Frazer and P. G. Young, "Phosphorylation mediated regulation of Cdc25 activity, localization and stability," in Protein Phosphorylation in Human Health, C. Huang, Ed., pp. 395-436, InTech, 2012.

[30] N. Debili, C. Robin, V. Schiavon et al., "Different expression of CD41 on human lymphoid and myeloid progenitors from adults and neonates," Blood, vol. 97, no. 7, pp. 2023-2030, 2001.

[31] H. Nakajima, "Role of transcription factors in differentiation and reprogramming of hematopoietic cells," Keio Journal of Medicine, vol. 60, no. 2, pp. 47-55, 2011.

[32] Y. Fukuchi, F. Shibata, M. Ito et al., "Comprehensive analysis of myeloid lineage conversion using mice expressing an inducible form of C/EBP $\alpha$, The EMBO Journal, vol. 25, no. 14, pp. 33983410, 2006.

[33] R. A. Shivdasani, "Molecular and transcriptional regulation of megakaryocyte differentiation," Stem Cells, vol. 19, no. 5, pp. 397-407, 2001.

[34] K. Terui, Y. Takahashi, J. Kitazawa, T. Toki, M. Yokoyama, and E. Ito, "Expression of transcription factors during megakaryocytic differentiation of CD34+ cells from human cord blood induced by thrombopoietin," Tohoku Journal of Experimental Medicine, vol. 192, no. 4, pp. 259-273, 2000.

[35] J. A. Trapani, M. Dawson, V. A. Apostolidis, and K. A. Browne, "Genomic organization of IFI16, an interferon-inducible gene whose expression is associated with human myeloid cell differentiation: correlation of predicted protein domains with exon organization," Immunogenetics, vol. 40, no. 6, pp. 415-424, 1994.

[36] M. J. Dawson, N. J. Elwood, R. W. Johnstone, and J. A. Trapani, "The IFN-inducible nucleoprotein IFI 16 is expressed in cells of the monocyte lineage, but is rapidly and markedly downregulated in other myeloid precursor populations," Journal of Leukocyte Biology, vol. 64, no. 4, pp. 546-554, 1998.

[37] M. Gariglio, M. De Andrea, M. Lembo et al., "The murine homolog of the HIN 200 family, Ifi 204, is constitutively expressed in myeloid cells and selectively induced in the monocyte/macrophage lineage," Journal of Leukocyte Biology, vol. 64, no. 5, pp. 608-614, 1998.

[38] A. F. Valledor, F. E. Borràs, M. Cullell-Young, and A. Celada, "Transcription factors that regulate monocyte/macrophage differentiation," Journal of Leukocyte Biology, vol. 63, no. 4, pp. 405-417, 1998.

[39] K. Krishnaraju, B. Hoffman, and D. A. Liebermann, "Early growth response gene 1 stimulates development of hematopoietic progenitor cells along the macrophage lineage at the expense of the granulocyte and erythroid lineages," Blood, vol. 97, no. 5, pp. 1298-1305, 2001.

[40] J. Dauffy, G. Mouchiroud, and R. P. Bourette, "The interferoninducible gene, Ifi204, is transcriptionally activated in response to M-CSF, and its expression favors macrophage differentiation in myeloid progenitor cells," Journal of Leukocyte Biology, vol. 79, no. 1, pp. 173-183, 2006.

[41] G. Marziali, E. Perrotti, R. Ilari, U. Testa, E. M. Coccia, and A. Battistini, "Transcriptional regulation of the ferritin heavychain gene: the activity of the CCAAT binding factor NF-Y is modulated in heme-treated Friend leukemia cells and during monocyte-to-macrophage differentiation," Molecular and Cellular Biology, vol. 17, no. 3, pp. 1387-1395, 1997.

[42] C. Shi, X. Zhang, Z. Chen et al., "Integrin engagement regulates monocyte differentiation through the forkhead transcription factor Foxp1," Journal of Clinical Investigation, vol. 114, no. 3, pp. 408-418, 2004.

[43] C. Shi, M. Sakuma, T. Mooroka et al., "Down-regulation of the forkhead transcription factor Foxpl is required for monocyte differentiation and macrophage function," Blood, vol. 112, no. 12, pp. 4699-4711, 2008.

[44] D. F. Smith, E. Galkina, K. Ley, and Y. Huo, "GRO family chemokines are specialized for monocyte arrest from flow," The American Journal of Physiology: Heart and Circulatory Physiology, vol. 289, no. 5, pp. H1976-H1984, 2005.

[45] J. J. Oppenheim, O. M. Z. Howard, and E. Goetzl, Chemotactic Factors, Neuropeptides, and Other Ligands for Seven Transmembrane Receptors, 2000.

[46] Y. Terashima, N. Onai, M. Murai et al., "Pivotal function for cytoplasmic protein FROUNT in CCR2-mediated monocyte chemotaxis," Nature Immunology, vol. 6, no. 8, pp. 827-835, 2005.

[47] Y. Lefkir, M. Malbouyres, D. Gotthardt et al., "Involvement of the AP-1 adaptor complex in early steps of phagocytosis and macropinocytosis," Molecular Biology of the Cell, vol. 15, no. 2, pp. 861-869, 2004.

[48] F. Niedergang and P. Chavrier, "Signaling and membrane dynamics during phagocytosis: many roads lead to the phagosome," Current Opinion in Cell Biology, vol. 16, no. 4, pp. 422428, 2004.

[49] D. Cox, D. J. Lee, B. M. Dale, J. Calafat, and S. Greenberg, "A Rabll-containing rapidly recycling compartment in macrophages that promotes phagocytosis," Proceedings of the National Academy of Sciences of the United States of America, vol. 97, no. 2, pp. 680-685, 2000.

[50] O. V. Vieira, C. Bucci, R. E. Harrison et al., "Modulation of Rab5 and Rab7 recruitment to phagosomes by phosphatidylinositol 3-kinase," Molecular and Cellular Biology, vol. 23, no. 7, pp. 25012514, 2003.

[51] T. Khurana, J. A. Brzostowski, and A. R. Kimmel, "A Rab21/LIM-only/CH-LIM complex regulates phagocytosis via both activating and inhibitory mechanisms," The EMBO Journal, vol. 24, no. 13, pp. 2254-2264, 2005. 
[52] S. J. Martin, J. G. Bradley, and T. G. Cotter, "HL-60 cells induced to differentiate towards neutrophils subsequently die via apoptosis," Clinical and Experimental Immunology, vol. 79, no. 3, pp. 448-453, 1990.

[53] A. Benito, D. Grillot, G. Nunez, and J. L. Fernandez-Luna, "Regulation and function of $\mathrm{Bcl}-2$ during differentiation-induced cell death in HL-60 promyelocytic cells," The American Journal of Pathology, vol. 146, no. 2, pp. 481-490, 1995.

[54] M. Lamkanfi, N. Festjens, W. Declercq, T. V. Berghe, and P. Vandenabeele, "Caspases in cell survival, proliferation and differentiation," Cell Death and Differentiation, vol. 14, no. 1, pp. 44-55, 2007.

[55] O. Sordet, C. Rébé, S. Plenchette et al., "Specific involvement of caspases in the differentiation of monocytes into macrophages," Blood, vol. 100, no. 13, pp. 4446-4453, 2002.

[56] T.-B. Kang, T. Ben-Moshe, E. E. Varfolomeev et al., "Caspase8 serves both apoptotic and nonapoptotic roles," Journal of Immunology, vol. 173, no. 5, pp. 2976-2984, 2004.

[57] H. Ichijo, E. Nishida, K. Irie et al., "Induction of apoptosis by ASK1, a mammalian MAPKKK that activates SAPK/JNK and p38 signaling pathways," Science, vol. 275, no. 5296, pp. 90-94, 1997.

[58] J. Cheng, J. Yang, Y. Xia, M. Karin, and B. Su, "Synergistic interaction of MEK kinase 2, c-Jun N-terminal kinase (JNK) kinase 2, and JNK1 results in efficient and specific JNK1 activation," Molecular and Cellular Biology, vol. 20, no. 7, pp. 2334-2342, 2000.

[59] J. L. Blank, P. Gerwins, E. M. Elliott, S. Sather, and G. L. Johnson, "Molecular cloning of mitogen-activated protein/ERK kinase kinases (MEKK) 2 and 3 regulation of sequential phosphorylation pathways involving mitogen-activated protein kinase and c-Jun kinase," Journal of Biological Chemistry, vol. 271, no. 10, pp. 5361-5368, 1996.

[60] S. Papa, F. Zazzeroni, C. G. Pham, C. Bubici, and G. Franzoso, "Linking JNK signaling to NF- $\kappa$ B: a key to survival," Journal of Cell Science, vol. 117, no. 22, pp. 5197-5208, 2004.

[61] T. Kadoya, A. Khurana, M. Tcherpakov et al., "JAMP, a JUB Nterminal kinase 1 (JNK1)-associated membrane protein, regulates duration of JNK activity," Molecular and Cellular Biology, vol. 25, no. 19, pp. 8619-8630, 2005.

[62] M. Qi and E. A. Elion, "MAP kinase pathways," Journal of Cell Science, vol. 118, no. 16, pp. 3569-3572, 2005.

[63] Q. Zhao and F. S. Lee, "Mitogen-activated protein kinase/ERK kinase kinases 2 and 3 activate nuclear factor- $\kappa \mathrm{B}$ through $\mathrm{I} \kappa \mathrm{B}$ kinase- $\alpha$ and $\mathrm{I} \kappa \mathrm{B}$ kinase- $\beta$," The Journal of Biological Chemistry, vol. 274, no. 13, pp. 8355-8358, 1999.

[64] H. Namba, V. Saenko, and S. Yamashita, "Nuclear factor- $\kappa$ B in thyroid carcinogenesis and progression: a novel therapeutic target for advanced thyroid cancer," Arquivos Brasileiros de Endocrinologia e Metabologia, vol. 51, no. 5, pp. 843-851, 2007.

[65] B. Feng, S. Cheng, W. S. Pear, and H.-C. Liou, "NF-kB inhibitor blocks B cell development at two checkpoints," Medical Immunology, vol. 3, article 1, 2004.

[66] S. Gerondakis and U. Siebenlist, "Roles of the NF-kappaB pathway in lymphocyte development and function," Cold Spring Harbor Perspectives in Biology, vol. 2, no. 5, Article ID a000182, 2010.

[67] K. P. Bhat, V. Balasubramaniyan, B. Vaillant et al., "Mesenchymal differentiation mediated by NF-kB promotes radiation resistance in glioblastoma," Cancer Cell, vol. 24, no. 3, pp. 331346, 2013. 


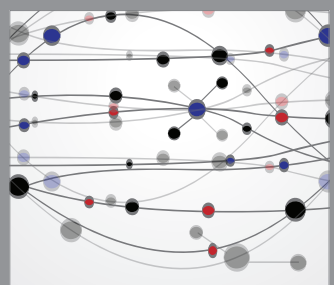

The Scientific World Journal
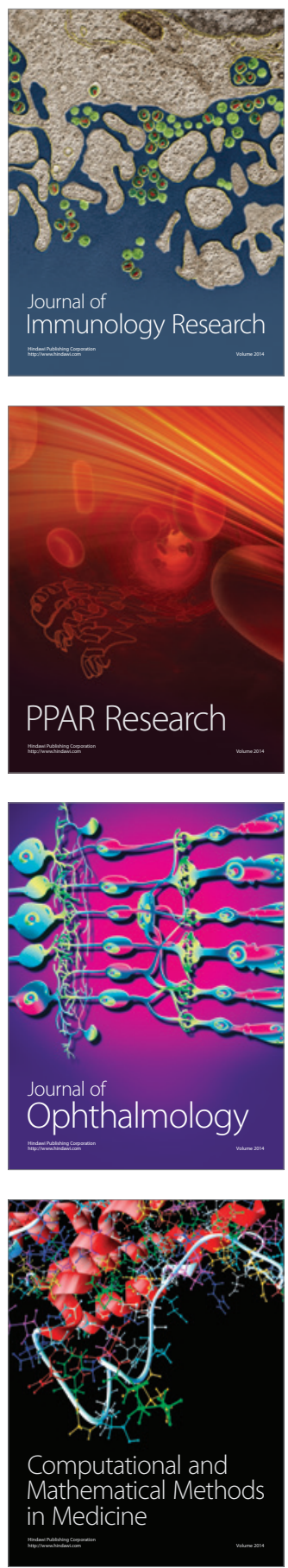

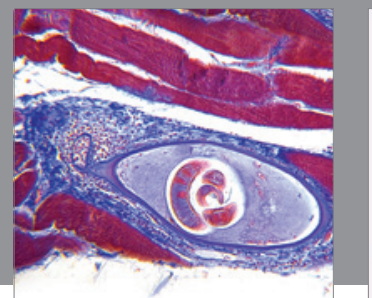

Gastroenterology

Research and Practice
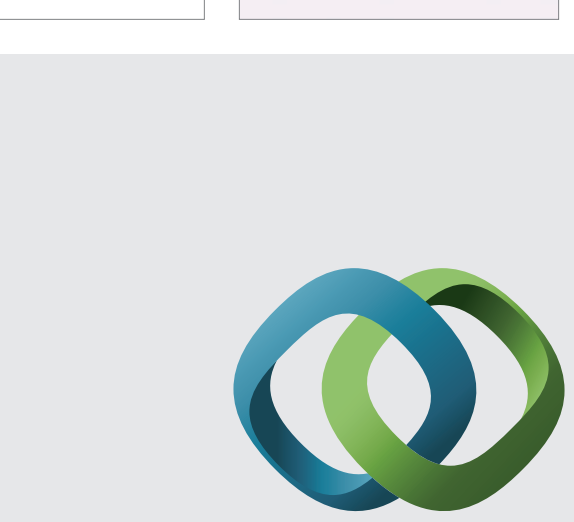

\section{Hindawi}

Submit your manuscripts at

http://www.hindawi.com
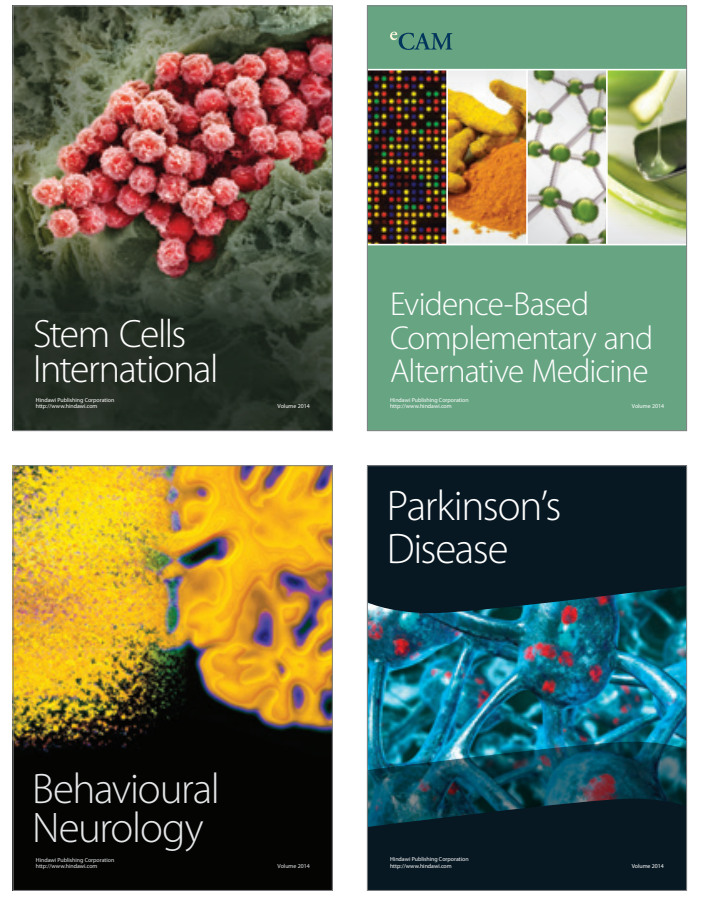
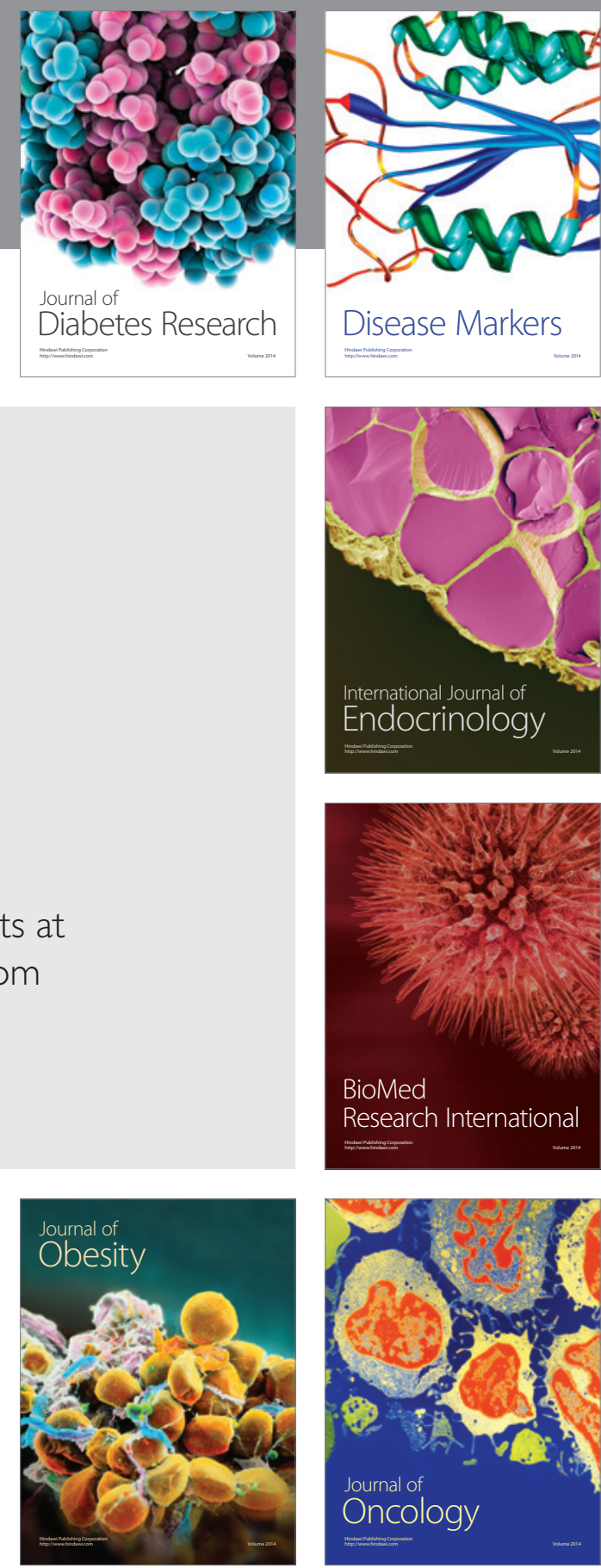

Disease Markers
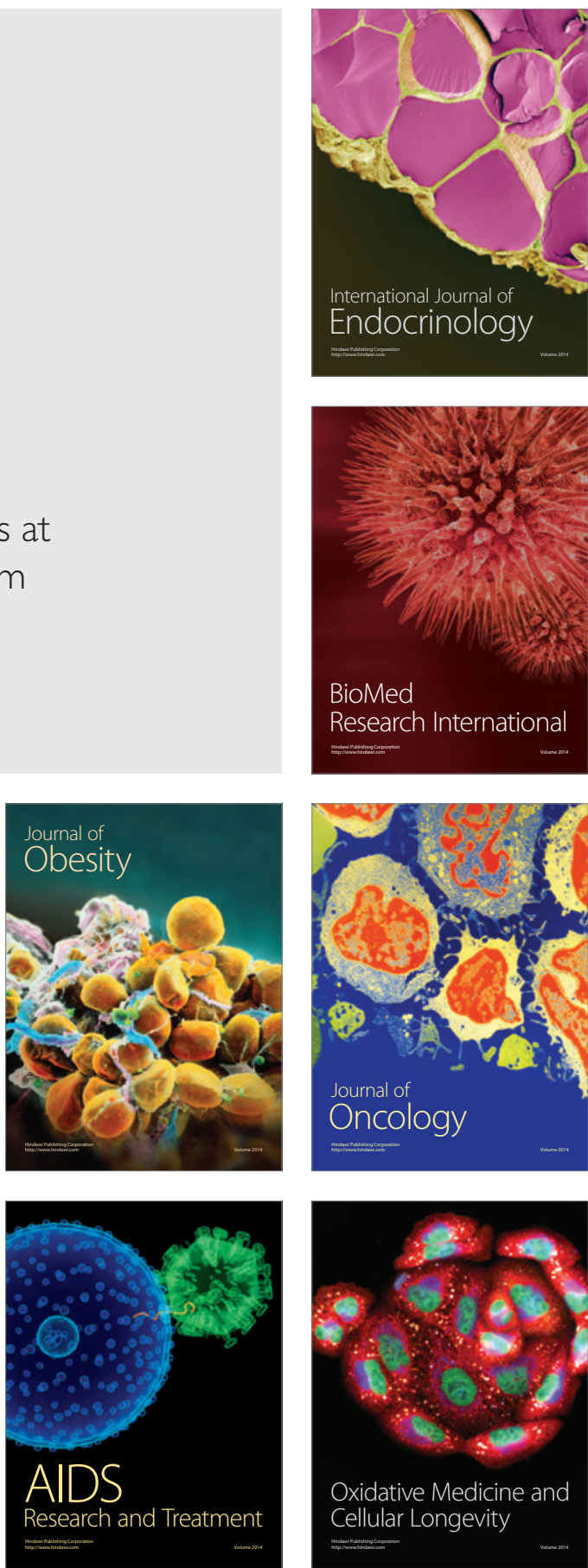